Original article

\title{
An overview of the crocodylian fossil record from Sardinia (Italy)
}

\author{
Un aperçu sur les crocodiles fossiles de Sardaigne (Italie) \\ Daniel Zoboli ${ }^{\mathrm{a}, *}$, Luigi Sanciu ${ }^{\mathrm{b}, \mathrm{c}}$, Gian Luigi Pillola ${ }^{\mathrm{a}}$, Massimo Delfino ${ }^{\mathrm{d}, \mathrm{e}}$ \\ a Dipartimento di Scienze Chimiche e Geologiche, Università di Cagliari, 51, via Trentino, 09127 Cagliari, Italy \\ b Centro Studi di Storia Naturale del Mediterraneo, Museo di Storia Naturale Aquilegia - GeoMuseo Monte Arci "Stefano Incani”, Via San Francesco, 09090 \\ Masullas, Italy \\ c P.AR.C., loc. S. Antine, 08030 Genoni, Italy \\ d Dipartimento di Scienze della Terra, Università di Torino, 35, via Valperga Caluso, 10125 Torino, Italy \\ e Institut Català de Paleontologia Miquel Crusafont, Universitat Autònoma de Barcelona, Edifici ICTA-ICP, Carrer de les Columnes s/n, Campus de la UAB, \\ 08193 Cerdanyola del Vallès, Barcelona, Spain
}

\section{A R T I C L E I N F O}

\section{Article history:}

Received 21 November 2018

Accepted 29 April 2019

Available online 29 May 2019

\section{Keywords:}

Crocodylidae

Tomistominae

Tomistoma calaritanum

Systematic Palaeontology

Cenozoic

Italy

\begin{abstract}
A B S T R A C T
In the present contribution we focus on an overview of the Cenozoic crocodylians of Sardinia (Italy). Crocodylians from this Italian island have been published since the second half of the 19th Century and a number of papers reported on the presence of these vertebrates in 16 different localities. The remains, some of which apparently lost, are mainly represented by isolated teeth housed in historical collections of different museums (in Italy and The Netherlands) that in most cases have never been figured or described. We illustrate for the first time and provide brief descriptions of all crocodylian teeth collected in the island as well as of the still available holotype of Tomistoma calaritanum, the only crocodylian taxon established on material from Sardinia. In addition, we report crocodylian remains from two new localities, one of which testifies the presence of these vertebrates already in the Eocene record of the island.
\end{abstract}

(C) 2019 Elsevier Masson SAS. All rights reserved.

\section{R É S U M É}

Dans la présente contribution, nous nous concentrons sur un aperçu des crocodyliens cénozoïques de Sardaigne (Italie). Les crocodiliens de cette île italienne ont été publiés depuis la seconde moitié du $19^{\mathrm{e}}$ siècle et un certain nombre d'articles ont fait état de la présence de ces vertébrés dans 16 localités différentes. Les restes, dont une partie semble avoir été perdue, sont principalement représentés par des dents isolées, conservés dans des collections historiques de différents musées (en Italie et aux Pays-Bas) qui, dans la plupart des cas, n’ont jamais été figurés ni décrits. Nous illustrons pour la première fois et fournissons une brève description de toutes les dents de crocodiliens collectées sur l'île ainsi que de l'holotype encore disponible de Tomistoma calaritanum, le seul taxon de crocodilien établi sur du matériel de Sardaigne. En outre, nous signalons des restes de crocodiliens de deux nouvelles localités, dont l'une témoigne de la présence de ces vertébrés déjà dans les dépots de l'Éocène de l'île.

(C) 2019 Elsevier Masson SAS. Tous droits réservés.

\section{Introduction}

\subsection{Palaeogeographic context}

The Sardinia-Corsica Massif represents a microplate located in the western Mediterranean basin, between the Liguro-Provençal

\footnotetext{
* Corresponding author.

E-mail address: zoboli.a@tiscali.it (D. Zoboli).
}

basin and the Tyrrenian Sea. It represents a segment of the Alpine orogenic system originally located in continuity with the southern European continental margin. From the early Miocene onwards, the Sardinia-Corsica Massif started to separate from the mainland with anticlockwise rotation (Vardabasso, 1962; Cherchi, 1974). Thus, the Sardinian Neogene fossils represent the oldest known case of endemic insular vertebrate faunas from the Mediterranean Sea (Mennecart et al., 2017). However, the palaeogeographic evolution of this area allowed different few immigration phases of mainland vertebrates during the Neogene (Azzaroli and Guazzone, 1979; Van 
der Made, 1999; Abbazzi et al., 2004, 2008a, 2008b) and especially during the Quaternary (Azzaroli, 1983; Palombo, 1985, 2009; Van der Made, 1999; Pillola and Zoboli, 2017; Zoboli and Caddeo, 2016; Zoboli and Pillola, 2016a, 2017a; Zoboli et al., 2016, 2018).

\subsection{Cenozoic Sandinian Paleoherpetology}

The Sardinian fossil record of Cenozoic herpetofaunas is rather interesting, though not abundant and certainly incomplete because many extant species have not been traced yet. However, members of each of the higher taxa currently inhabiting the northern hemisphere have been identified: Squamata (Serpentes, Amphisbaenia, "Lacertilia"), Testudines, and Crocodylia. Squamates were reported from the early Miocene (Oschiri; Venczel and Sanchiz, 2006) to the Holocene (Delfino, 2002). Among snakes, worth mentioning is the "exotic" presence of an extinct aniilid snake, Eoanilius oligocenicus, at Oschiri (Venczel and Sanchiz, 2006) and the holotype and only specimen of the booid snake Palaeopython sardus Portis, 1901 (Portis, 1901a), that was recently identified as an undetermined fish (Delfino et al., 2014). Booid snakes were in any case present in Sardinia during the late Pliocene as testified by Eryx from Capo Mannu (D1 Local Fauna; Delfino et al., 2011). The Pleistocene karst fissures of Monte Tuttavista (Abbazzi et al., 2004) yielded thousands of disarticulated snake remains (mostly isolated vertebrae) belonging to a viperid, a still undescribed new colubrid species, and a grass snake of the genus Natrix. The viper of Monte Tuttavista along those of two other sites (Venczel and Sanchiz, 2006; Delfino et al., 2011) represents the only Sardinian evidence for this group of snakes currently extinct on the island (Sindaco et al., 2006). Colubrid snakes (colubrines and Natrix) were also identified at Capo Mannu (D1 Local Fauna; Delfino et al., 2011) and in some Quaternary sites (Delfino, 2002).

Lizards are represented at Monte Tuttavista by the most abundant and informative European remains of agamids (Delfino et al., 2008), by the first evidence in Sardinia of a large-sized lacertid lizard that recently turned out to belong to Timon (Tschopp et al., 2018), as well as by smaller lacertid lizards and geckos (Abbazzi et al., 2004). Anguid lizards referred to the genus Dopasia have been reported from the early Miocene of Oschiri (Venczel and Sanchiz, 2006) and the Pliocene of Capo Mannu (D1 Local Fauna; Delfino et al., 2011); the latter was recently identified as Ophisaurus spinari by Klembara and Rummel (2018). Skinks have been also cited or described from the Miocene of Oschiri (Venczel and Sanchiz, 2006) to the Holocene (Delfino, 2002), but their record is very scarce.

In the Pliocene of Capo Mannu (D1 Local Fauna; Delfino et al., 2011) and Pleistocene of Monte Tuttavista (Abbazzi et al., 2004) amphisbaenians are also present and likely belong to the Blanidae. They were already present in the early Miocene of the island (Oschiri) with Blanus gracilis Roček 1984 (Venczel and Sanchiz, 2006).

Fossil turtles are rather common in Sardinia and, with a single exception, are all represented by Neogene and Quaternary cryptodires. One exception consists of a still underscribed pleurodire from the Eocene of Cixerri that was preliminary referred to Erymnochelys (Delfino and Rook, 2008a). Among the cryptodires, softshell turtles are present in a few Eocene and Miocene localities. A revision of Procyclanorbis sardus (Portis, 1901b) revealed that the name is a nomen dubium and the type is actually an indeterminate pan-trionychine (see Georgalis et al., 2017, and references therein). Testudinids are represented by an extinct species, Testudo pecorinii Delfino, 2008 (in Abbazzi et al., 2008a), from the late Pliocene of Capo Mannu D4 local fauna (San Vero Milis) and by Testudo cf. T. hermanni from the Pleistocene of Monte Tuttavista (Abbazzi et al., 2004). Zoboli (2017) reported a large-size phalanx of a probable testudinid from the Major's Collection of the Naturhistorisches Museum Basel. The fossil was collected in the bone breccias of Monte San Giovanni (southern Sardinia) and could testify for the presence of a giant tortoise in the?Late Pleistocene of Sardinia.

Freshwater turtles have been described in a few localities. Fragmentary remains representing the last Italian evidence of $\mathrm{Mau}$ remys come from the Late Pleistocene of San Giovanni di Sinis (Chesi et al., 2007), whereas a well-preserved carapace of Emys orbicularis comes from Grotta di Monte Meana, near Santadi (Chesi et al., 2008). Marine turtles, referred to Cheloniidae indet., are present in the early Miocene of Noragugume (Chesi, 2008) and in the late Miocene of Cagliari (Zoboli and Pillola, 2016b). Trachyaspis lardyi was identified in the Miocene of Bosa (Chesi, 2008) and Caretta, was reported only in Holocene archaeological sites (Wilkens, 2003; Delussu, 2007).

The first fossil crocodylians of Sardinia have been published since the second half of the 19th Century (Gennari, 1868; Capellini, 1890a, 1890b) and since then a number of papers reported on the presence or described remains in localities of different subregions of the Island (Fig. 1). The remains, all Miocene in age, are represented in most of the cases by isolated teeth (see below), but also a nearly complete skull and lower jaw (and associated few postcranial elements such as osteoderms and vertebrae) on the basis of which a new species of tomistomine, Tomistoma calaritanum Capellini, 1890, was described (as Tomistoma calaritanus, see below; Capellini, 1890b). Due to the number of papers published on the subject (often in old Italian local journals, see references below), the damage and loss suffered by the type material of $T$. calaritanum and its convoluted taxonomic and nomenclatural history, it is here presented an overview on the crocodylian fossil record of Sardinia, with a reassessment of the identifications published in the past.

\section{The crocodilian fossil record of Sardinia}

The Sardinian crocodylian fossils herein illustrated are housed in historical collections of different museums. Unpublished materials from two new localities, one of which pushing back to the Eocene the presence of crocodylians in the island, are also described.

Institutional Abbreviations: MDLCA, Museo Sardo di Geologia e Paleontologia Domenico Lovisato, Cagliari, Italy; PARC, Paleo Archeo Centro, Genoni, Italy; MACPL, GeoMuseo Monte Arci "Stefano Incani”, Masullas, Italy; MGPT-PU, Museo di Geologia e Paleontologia dell'Università degli Studi di Torino, Turin, Italy; UU, University of Utrecht, Utrecht, The Netherlands.

\subsection{Ypresian}

\subsubsection{Locality}

Escalaplano (Sarrabus-Gerrei subregion, southern Sardinia).

Age and geological setting: Monte Cardiga Formation (early Eocene, Ypresian; Cherchi, 1985). The Monte Cardiga Fm. is a lithostratigraphic unit discontinuously cropping out in the southeastern Sardinia (Salto di Quirra, Sarrabus-Gerrei, Ogliastra). In the Escalaplano and Perdasdefogu areas this formation overlies the Palaeozoic basement and the Mesozoic lithologies (Vardabasso, 1962). At the bottom, the Monte Cardiga Fm. is represented by polygenic conglomerates, sandstones with siliceous cement and marly sandstones with scarce plant remains. In the upper part, marls, calcarenites and bioclastic limestones with a rich foraminiferal fauna are predominant; locally, layers of polygenic conglomerates are present. Furthermore, several levels of calcarenite rich in gastropods (cerithids) and other marine invertebrates are present in the medium-basal portion of the sequence. The crocodile tooth was collected in one of these levels cropping out at the southern periphery of the village of Escalaplano. The Monte Cardiga Fm. is referred 


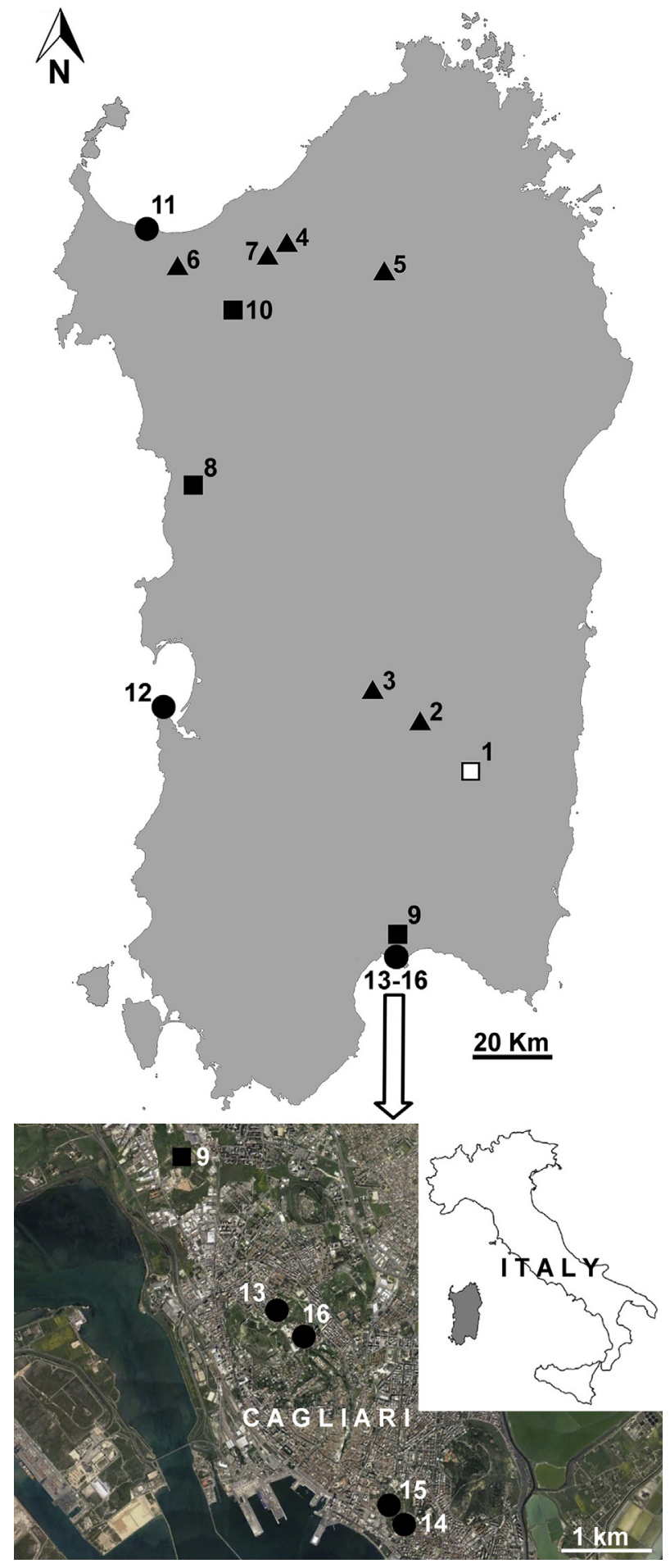

Fig. 1. Sardinian Cenozoic crocodylian-bearing localities: 1, Escalaplano; 2, Cava Duidduru (Genoni); 3, Strintu de Melonis and Comidiano (Nurri); 4, Laerru; 5, Oschiri; 6, La Crucca(Sassari); 7, Monte Orria (Nulvi); 8, Tresnuraghes; 9, Bingia Fargeri (Cagliari); 10, Florinas; 11, Fiume Santo (Porto Torres); 12, Capo Frasca (Arbus); 13, Tuvumannu; 14, Bonaria and Montixeddu di Bonaria - Cava Timon; 15, Cimitero Monumentale di Bonaria; 16, Is Mirrionis - Piazza d'Armi. White square: Ypresian, triangles: ?Chattian-Burdigalian, black squares: Langhian-Serravallian, circles: Tortonian-Messinian.

Localités cénozoïques ayant livré de restes des crocodiles : 1 , Escalaplano ; 2, Cava Duidduru (Genoni) ; 3, Strintu de Melonis et Comidiano (Nurri) ; 4, Laerru ; 5, Oschiri ; 6, La Crucca (Sassari) ; 7, Monte Orria (Nulvi) ; 8, Tresnuraghes ; 9, Bingia Fargeri (Cagliari) ; 10, Florinas ; 11, Fiume Santo (Porto Torres); 12, Capo Frasca (Arbus); 13, Tuvumannu ; 14, Bonaria et Montixeddu di Bonaria - Cava Timon; 15, Cimitero Monumentale di Bonaria ; 16, Is Mirrionis - Piazza d'Armi. Carré blanc : Yprésien, triangles : ?ChattienBurdigalien, carrés noirs : Langhien-Serravallien, cercles : Tortonien-Messinien. to the Ypresian on the basis of the micropalaeontological content (Cherchi, 1985).

Taxon: Crocodylia indet.

Material: MACPL 1364, one isolated tooth (Fig. 2A).

Description and remarks: The isolated tooth is still embedded in the calcarenite matrix and only what appears to be a moderately altered lingual surface is visible. The apex is broken off and the root is missing. The preserved portion of the crown is $7.7 \mathrm{~mm}$ long. The associated marine fauna suggests the transport of the crocodylian remains from the emerged areas to the seaside.

\section{2. ?Chattian-Burdigalian}

\subsubsection{Locality \\ "Cava Duidduru" (Genoni, Sarcidano subregion, central Sar- dinia).}

Age and geological setting: Nurallao Formation (?Chattian early Burdigalian, Funedda et al., 2011). The isolated crocodylian tooth was collected in the "Cava Duidduru", an abandoned quarry currently reconverted in a geosite. The quarry is opened in the? Chattian - early Burdigalian marine succession of the Nurallao Fm. (Funedda et al., 2011) belonging to the first Cenozoic sedimentary cycle of Sardinia. The Nurallao Fm. is represented by marine-littoral sediments and is divided in two members: Conglomerato di Duidduru member (at the bottom) and Arenarie di Serra Longa member (at the top). The lower member is constituted by polygenic and heterometric conglomerates mainly resulting from the erosion of the underlying Palaeozoic basement and subordinately by Cenozoic volcanites. The fossil content is represented especially by fragments of bivalve shells. The lithology changes both laterally and vertically in the sandstone and silicoclastic sands of the Arenarie di Serra Longa member. This latest member is represented by sands and microconglomerates that laterally and vertically change in coarse sandstones with carbonate cement. Furthermore, decimetric-conglomerate levels with elements of quartz, metamorphites and granitoids, and tanatocenosis dominated by bivalves and echinids are present. In the Duidduru quarry is present only this last member of the Nurallao Fm. The crocodylian tooth was found in a poorly-cemented grey sandstone level rich in fragments of carbonized plants, turritelline gastropods and crab-shell fragments. This level seems to testify a proximal depositional environment characterized by fluvial transport and deposition of organic material in a coastal lagoon. To date, the crocodylian remains and a mandible of a small ruminant (Mennecart et al., 2017) are the only continental vertebrates collected in the marine deposits of the latest Oligocene - early Miocene of central Sardinia.

Taxon: Crocodylia indet.

Material: PARC 205626, one isolated tooth (Fig. 2B).

Description and remarks: The tooth is represented by a portion of the crown missing its apex and, probably, its base. The preserved portion, $22.3 \mathrm{~mm}$ long, is relatively stout. Mesiodistal carinae are present but weakly developed (Fig. 2B5).

\subsubsection{Localities}

Strintu de Melonis and Comidiano, between Strintu Argiolu and the train station of Nurri (Nurri, Sarcidano subregion, central Sardinia).

Age and geological setting: Nurallao Formation (?Chattian early Burdigalian, Funedda et al., 2001, see above).

Taxon: Crocodylia indet. (=?Tomistoma sp. in Lovisato, 1892; Tomistoma calaritanus in Del Vecchio, 1921, Spano, 1985; Crocodylia indet. in Kotsakis et al., 2004; Tomistoma calaritanus in the original label of MGPT-PU).

Material: MGPT-PU 17336, one isolated tooth (Fig. 2C).

Description and remarks: Two incomplete crocodile teeth, previously referred to?Tomistoma sp. (Lovisato, 1892), were collected 


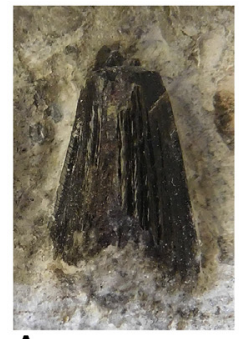

A
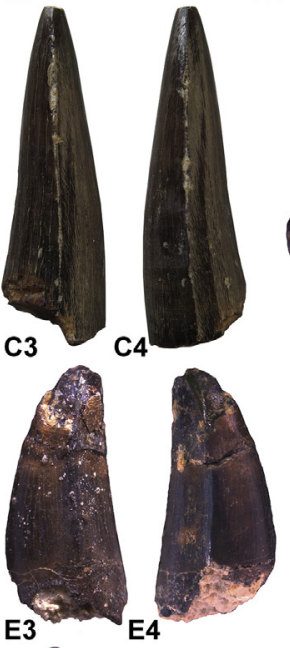

E3

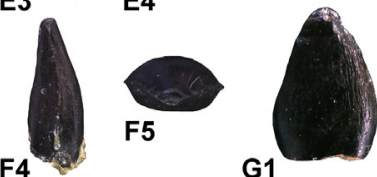

G1

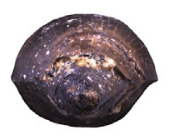

E5

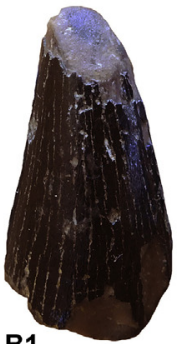

B1

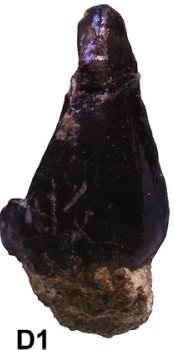

D1

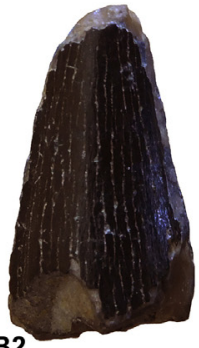

B2

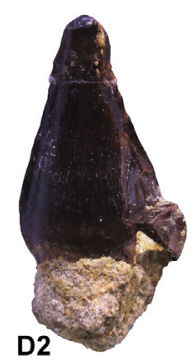

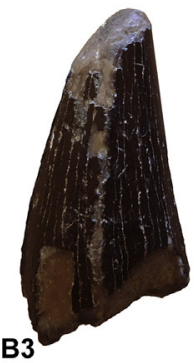

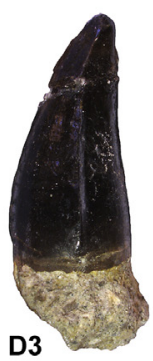

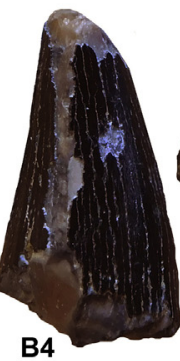

B4

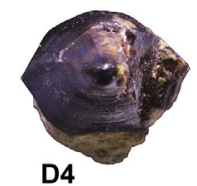

D4

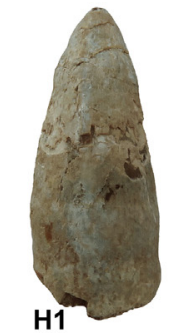

D2

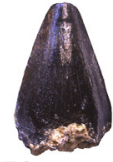

F1

E1
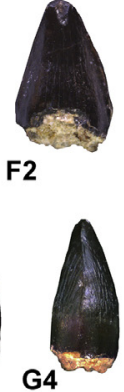

G2
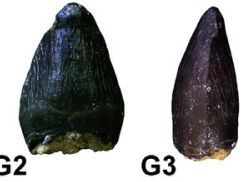

G3
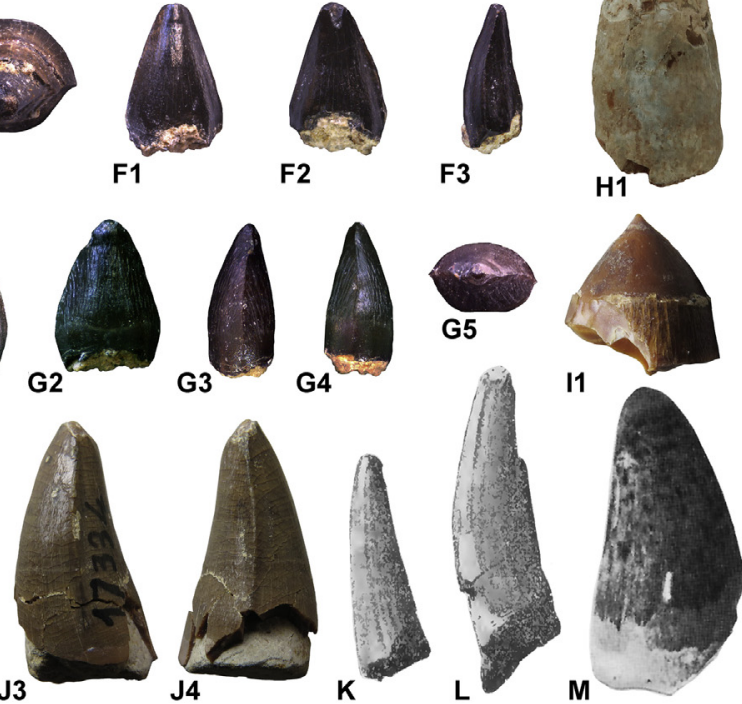

$\mathrm{H} 2$

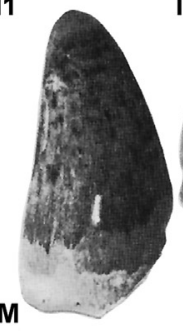

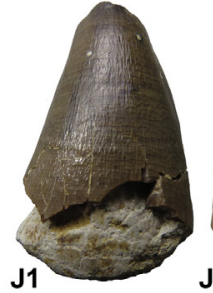

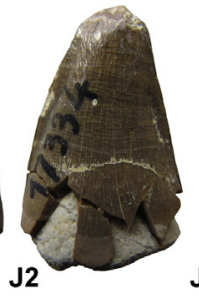

J3
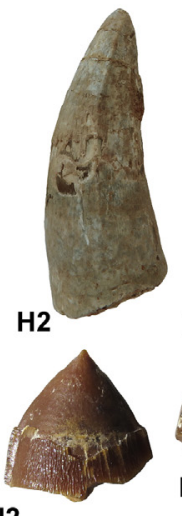

H3

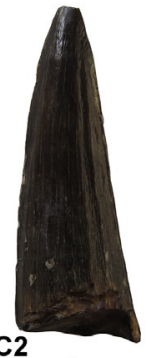

C1
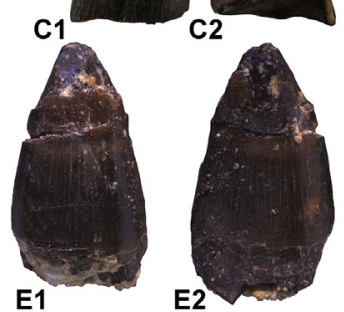

E2
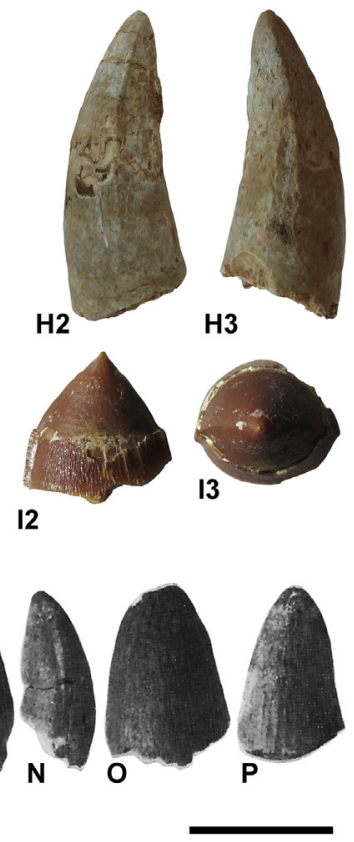

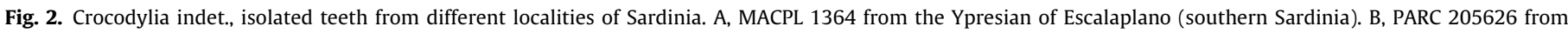

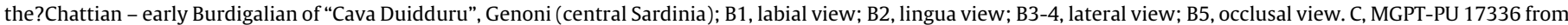

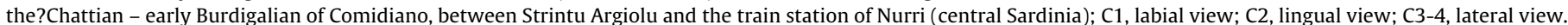

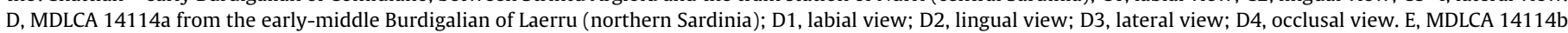

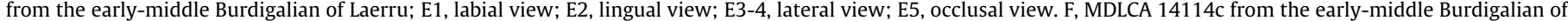

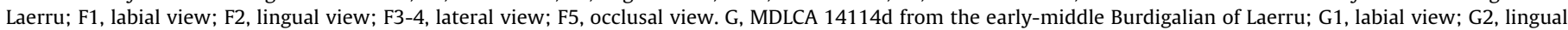

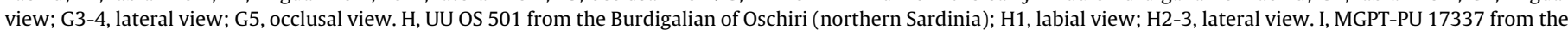

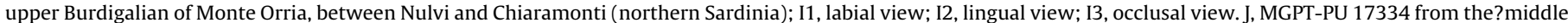

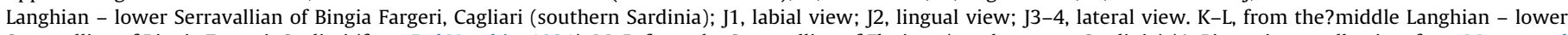

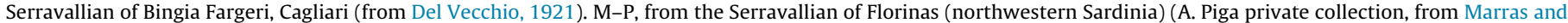
Ventura, 1985). Scale bar for A, E, F: $0.5 \mathrm{~cm}$; scale bar for B, C, I, J: $1 \mathrm{~cm}$; scale bar for D: $0.6 \mathrm{~cm}$; scale bar for G: $0.3 \mathrm{~cm}$; scale bar for H: $1.5 \mathrm{~cm}$; scale bar for K-P: $2 \mathrm{~cm}$.

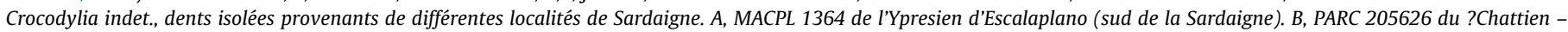

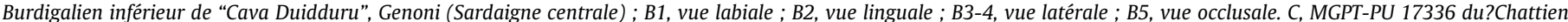

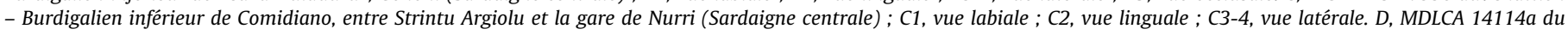

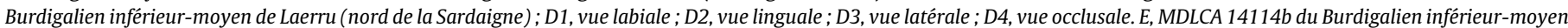

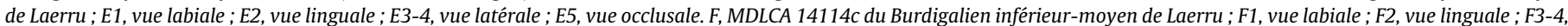

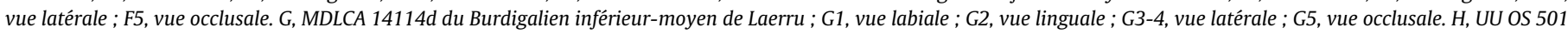

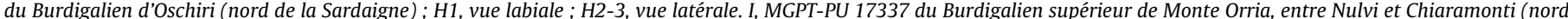

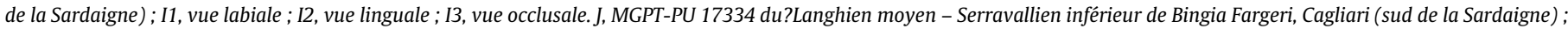

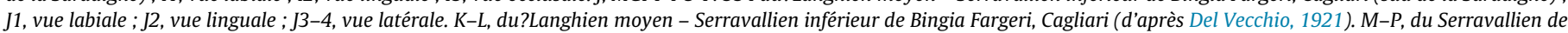

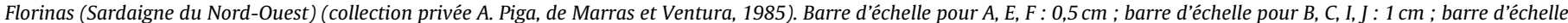
pour $D: 0,6 \mathrm{~cm}$; barre d'échelle pour $G: 0,3 \mathrm{~cm}$; barre d'échelle pour $H: 1,5 \mathrm{~cm}$; barre d'échelle pour $K-P: 2 \mathrm{~cm}$.

by Lovisato in a marly limestone cropping out in the southern suburbs of the village of Nurri, near the cemetery of the village (Strintu de Melonis) (Lovisato, 1892). Del Vecchio (1921) listing the crocodile teeth housed in Cagliari reported a single tooth of
Tomistoma calaritanus from Comidiano, between Strintu Argiolu and the train station of Nurri. Currently, the teeth from Strintu de Melonis are lost whereas the tooth from Comidiano is housed in Turin and accessioned as MGPT-PU 17336. It is a slender and 
pointed tooth crown, $21.6 \mathrm{~mm}$ long, with sparse, weak longitudinal ridges on the labial and lingual surfaces.

\subsubsection{Locality}

Laerru (Anglona subregion, northern Sardinia).

Age and geological setting: Perfugas Formation (early-middle Burdigalian, between $18.83 \pm 0.13$ and $18.29 \pm 0.13 \mathrm{Ma}$; Oudet et al., 2010; Sowerbutts, 2000). The fossiliferous site is located on the northern periphery of the village of Laerru. An epiclastic pomiceus-cineritic level underlies silicified lacustrine carbonates of the lower part of the Perfugas Formation (Sowerbutts, 2000). This fossiliferous epiclastic level is divided into three different layers, the majority of the vertebrate remains coming from the top of the lower layer (Zoboli and Pillola, 2017b; Mennecart et al., 2019). In the Anglona subregion, the lower part of the Perfugas Fm. comprises continental lacustrine deposits represented by finely bedded limestones and tuffs (Sowerbutts, 2000).

Taxon: Crocodylia indet. (=cf. Diplocynodon sp. in Zoboli and Pillola, 2017b).

Material: MDLCA 14114a-d, four isolated teeth (Fig. 2D-G).

Description and remarks: Zoboli and Pillola (2017b) recently described an interesting early Miocene vertebrate fauna from Laerru. Four tiny (crown length of the biggest tooth $=0.9 \mathrm{~cm}$, buccolabial diameter $=0.3$ ) and incomplete isolated crocodilian teeth were preliminary referred to cf. Diplocynodon sp. However, due to the generalized shape of the teeth and therefore the absence of diagnostic characters, the material is here referred to Crocodylia indet. Noteworthy is that Diplocynodon is currently considered a European endemic and was never reported in insular environments as expected for an alligatoroid that could have shared salt-water intolerance with extant alligatorids (Taplin and Grigg, 1989; Delfino et al., 2007; Delfino and Rossi, 2013).

\subsubsection{Locality}

Oschiri (Monteacuto subregion; northern Sardinia).

Age and geological setting: "Formazione lacustre" Auct. = Perfugas Fm. (Burdigalian, MN3; Van der Made, 2008; Zoboli and Pillola, 2017b). The vertebrate site is represented by a small exposure of lacustrine clay in a road cut near the village of Oschiri (De Bruijn and Rümke, 1974). The age of the mammal assemblage of Oschiri has been discussed by several authors (e.g. De Bruijn and Rümke, 1974; Azzaroli and Guazzone, 1979; Azzaroli, 1983; Van der Made, 2008). The micromammals are quite diverse, with nine taxa including seven endemic species (De Bruijn and Rümke, 1974). The advanced endemism of Ctenodactylidae and the presence of Gliridae, Talpidae and Soricidae are very similar to the mainland taxa, and suggest different phases of colonization of the Corsica Sardinia Massif (Ferrandini et al., 2000; Mennecart et al., 2017, 2019). The Oligo-Miocene palaeogeographical context of the western Mediterranean indicates that the latest additions to the insular association arrived in Sardinia during the European Land Mammal Unit MN3, which is coincident with the early Burdigalian marine regression, around $20 \mathrm{Ma}$ ago (Van der Made, 2008; Zoboli and Pillola, 2017b).

Taxon: Crocodylia indet.

Material: UU OS 501, one isolated tooth (Fig. 2H).

Description and remarks: The occurrence of crocodylians at Oschiri is already known in the literature according to Delfino et al. (2011: 379, tab. 1) who reported the presence of "an unpublished isolated tooth stored in the collections of Utrecht University (specimen unnumbered)". This isolated tooth, now UU OS 501, is rather large because even if devoid of most of the root, is $28.6 \mathrm{~mm}$ tall and has a labio-lingual diameter of $11.3 \mathrm{~mm}$ (the mesiodistal diameter is slightly smaller but this could be due to preservational reasons). The tooth is conical and slightly bent in lingual direction. The surface is variably damaged, nevertheless the mesiodisal carina is well visible and smooth. The conical depression that is likely present at the base is still filled with sediment.

\subsubsection{Locality}

La Crucca (Sassari, Sassarese subregion, northwestern Sardinia).

Age and geological setting: Mores Formation (upper Burdigalian). The crocodylian fossil remains were collected in a compact limestone level of the Mores Fm. (upper Burdigalian) cropping out in the locality of La Crucca, about eight kilometers West of Sassari (Spano, 1985).

Taxon: cf. Tomistoma sp. (=Tomistoma calaritanus in Spano, 1985; Crocodylia indet. in Kotsakis et al., 2004).

Material: two lumbar vertebrae, two sacral vertebrae, two caudal vertebrae, ilium, fragment of left ischium, some rib fragments, right femur, some osteoderms from the caudal region (Fig. 3).

Description and remarks: The material from La Crucca belongs to a single individual briefly described and only partially figured by Spano (1985). Despite the fact that we have not been able to locate this material, thanks to the published illustrations it is possible to refer it to a tomistomine crocodylian on the basis of the broad and anteroposteriorly short osteoderms whose ornamentation is represented by relatively few but large pits (compare Fig. 3A with the type osteoderms of Tomistoma calaritanum in Fig. 8; see also Piras et al., 2007; Nojima and Itoigawa, 2017; Shan et al., 2017).

\subsubsection{Locality}

Monte Orria (between Nulvi and Chiaramonti, Anglona subregion, northern Sardinia).

Age and geological setting: Mores Formation (upper Burdigalian). A middle Miocene age has been attributed by Spano (1985) to the material from Monte Orria, instead Kotsakis et al. (2004) indicated a late Miocene age. However, only the upper Burdigalian littoral carbonatic lithofacies of the Mores Fm. is reported in the Monte Orria area. The original label of MGPT-PU 17337 indicates that the only available tooth from Monte Orria was collected in a breccious limestone.

Taxon: Crocodylia indet. (=Crocodylia indet. in Del Vecchio, 1921; Spano, 1985; Kotsakis et al., 2004; Tomistoma calaritanus in the original label of MGPT-PU).

Material: MGPT-PU 17337, one isolated tooth (Fig. 2I).

Description and remarks: Del Vecchio (1921) listing the material collected in Cagliari reported several small fragments of small teeth from Monte Orria, between Nulvi and Chiaramonti. However, only one isolated tooth from this locality is currently housed in Turin. MGPT-PU 17337 is a small, and poorly preserved crown, $9.5 \mathrm{~mm}$ long that is nearly completely enamel-free.

\subsection{Langhian-Serravallian}

\subsubsection{Locality}

Tresnuraghes (Planargia subregion, western Sardinia).

Age and geological setting: "Crabs-rich" marly limestone (Langhian).

Taxon: Crocodylia indet. (=Tomistoma sp. in Lovisato, 1892; Tomistoma calaritanus and Crocodylia indet. in Del Vecchio, 1921; Crocodylia indet. in Kotsakis et al., 2004).

Material: not available.

Remarks: Lovisato (1892) reported two isolated teeth from this locality and referred them to Tomistoma sp. Del Vecchio (1921) listing the material housed in Cagliari reported two teeth different in size (the smallest referred to Tomistoma calaritanus and the largest to Crocodylia indet.). These teeth are currently not available and it is therefore impossible to provide a description.

\subsubsection{Locality}

Bingia Fargeri, Fangario (Cagliari). 


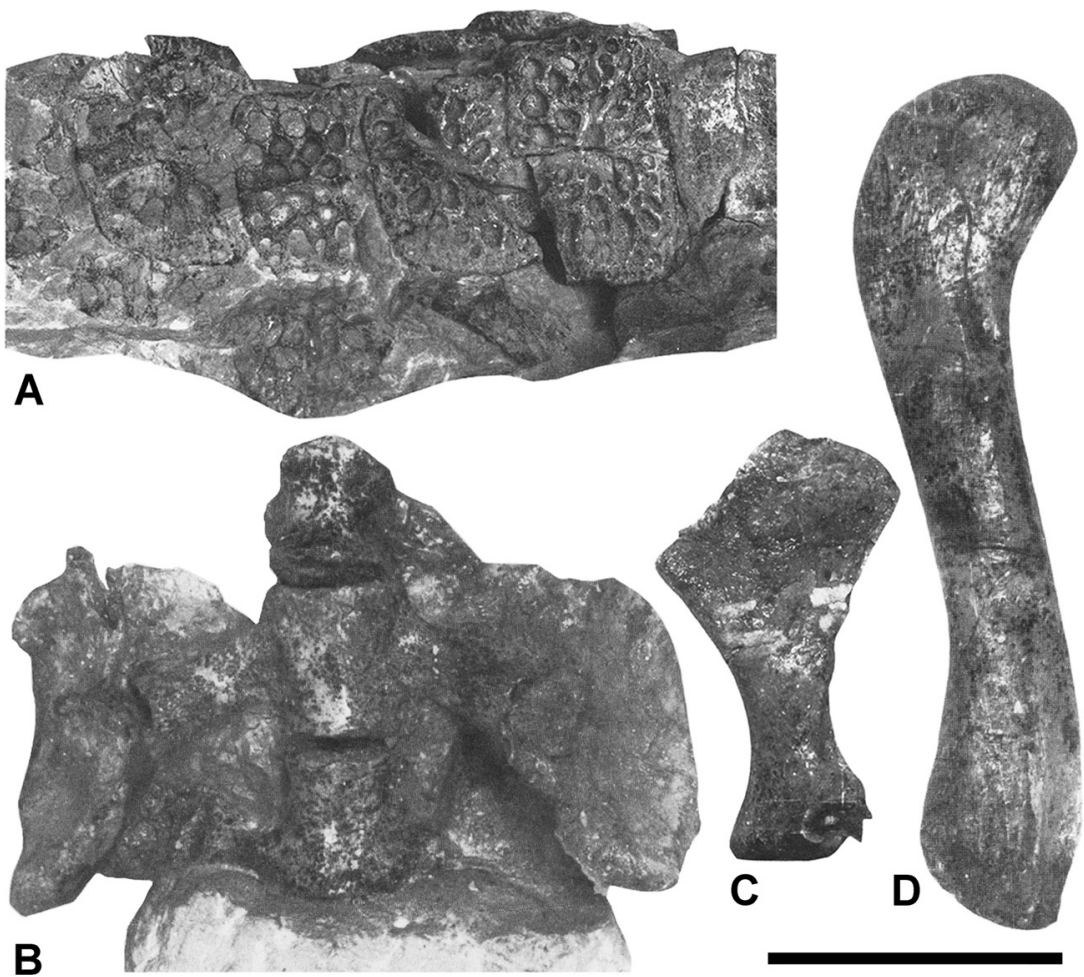

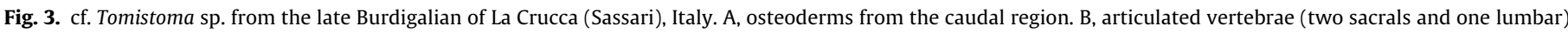
and iliac bones, ventral view. C, incomplete left ischium. D, right femur. Scale bar: $10 \mathrm{~cm}$. All figures modified from Spano, 1985 .

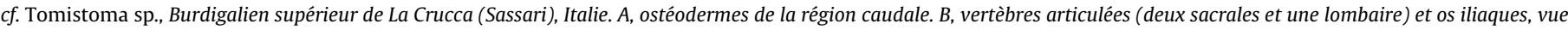
ventrale. C, ischium gauche incomplet. D, fémur droit. Barre d'échelle : $10 \mathrm{~cm}$. Tous les figures d'après Spano, 1985.

Age and geological setting: Argille di Fangario Formation (?middle Langhian - lower Serravallian). The Argille di Fangario Fm. is represented by clayey and/or sandy gray-yellowish marls, developing upward to marly sandstones, with foraminifers, corals, brachiopods, echinoids, molluscs and ichthyolitic fragments, The micropalaeontological content allows to refer this succession to the?middle Langhian - lower Serravallian (Cherchi, 1974).

Taxon: Crocodylia indet. (= Tomistoma cf. Tomistoma calaritanus in Capellini, 1890b; Tomistoma sp. in Lovisato, 1892; Tomistoma calaritanus in Del Vecchio, 1921; Tomistoma calaritanus in Spano, 1985; Crocodylia indet. in Kotsakis et al., 2004; Crocodylus calaritanus in the original label of MGPT-PU).

Material: MGPT-PU 17334, one incomplete isolated tooth (Fig. 2J). Two isolated teeth figured by Del Vecchio, 1921 (Fig. 2K and $\mathrm{L}$ ).

Description and remarks: Capellini (1890b) reported an incomplete tooth collected by Lovisato at Bingia Fargeri. The author referred the fossil to Tomistoma cf. calaritanus but Lovisato (1892) referred the tooth to Tomistoma sp. Later on, Del Vecchio (1921) described and figured two elongated teeth attributed to Tomistoma calaritanus from Bingia Fargeri (Fig. 2K and L). In addition, the author mentioned a third elongated tooth from the same locality. The only available tooth from Bingia Fargeri is now MGPT-PU 17334. It is not possible to correlate the sample housed in Turin with the material mentioned but not figured by Capellini (1890b) and Lovisato (1892). Furthermore, MGPT-PU 17334 is too different from those illustrated by Del Vecchio (1921). MGPT-PU 17334 is a massive crown, $21.5 \mathrm{~mm}$ tall, with a worn apex and the surface of the base only partly preserved. However, most of both the labial and lingual surface is preserved and distinctly smooth.

\subsubsection{Locality}

Florinas (Sassarese subregion, northwestern Sardinia).
Age and geological setting: Florinas Formation (Serravallian) The teeth were found in a sand quarry about two kilometers South of the village of Florinas.

Taxon: Crocodylia indet. (=?Tomistoma lusitanica in Marras and Ventura, 1985; Crocodylia indet. in Kotsakis et al., 2004).

Material: four isolated teeth. According to Marras and Ventura, 1985 (pp. 25), these teeth were hosted in a private collection: "Si ringrazia il sig. Alberto Piga per averci gentilmente prestato il materiale [Mr. Alberto Piga is thanked for having kindly loaned us the material]". We have not been able to locate the material.

Remarks: The teeth were previously described and figured by Marras and Ventura (1985). The authors doubtfully ascribed the fossils to Tomistoma lusitanica (Vianna and Moraes, 1945).

\subsection{Tortonian-Messinian}

\subsubsection{Locality}

Fiume Santo (Porto Torres, Nurra subregion, northwestern Sardinia).

Age and geological setting: Alluvial deposit (Tortonian - early Messinian). Several isolated crocodylian teeth were collected in the site of Fiume Santo, in upper Miocene alluvial sediments of the third Miocene sedimentary cycle recognized in Sardinia. The detailed stratigraphic data and the geological context of the site of Fiume Santo are not satisfactorily known, however, a late Tortonian - early Messinan age is suggested by the associated Turolian mammal fauna (Abbazzi et al., 2008b; Casanovas-Vilar et al., 2011).

Taxon: Crocodylia indet. (=Crocodylia indet. in Kotsakis et al. 2004; Abbazzi et al., 2008b).

Material: 49 isolated teeth (unumbered) hosted in the collections of the Soprintendenza Archeologia, belle arti e paesaggio per le province di Sassari e Nuoro (Fig. 5M and N). 


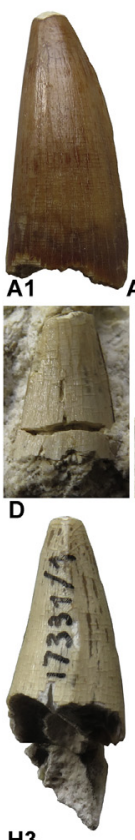

H3
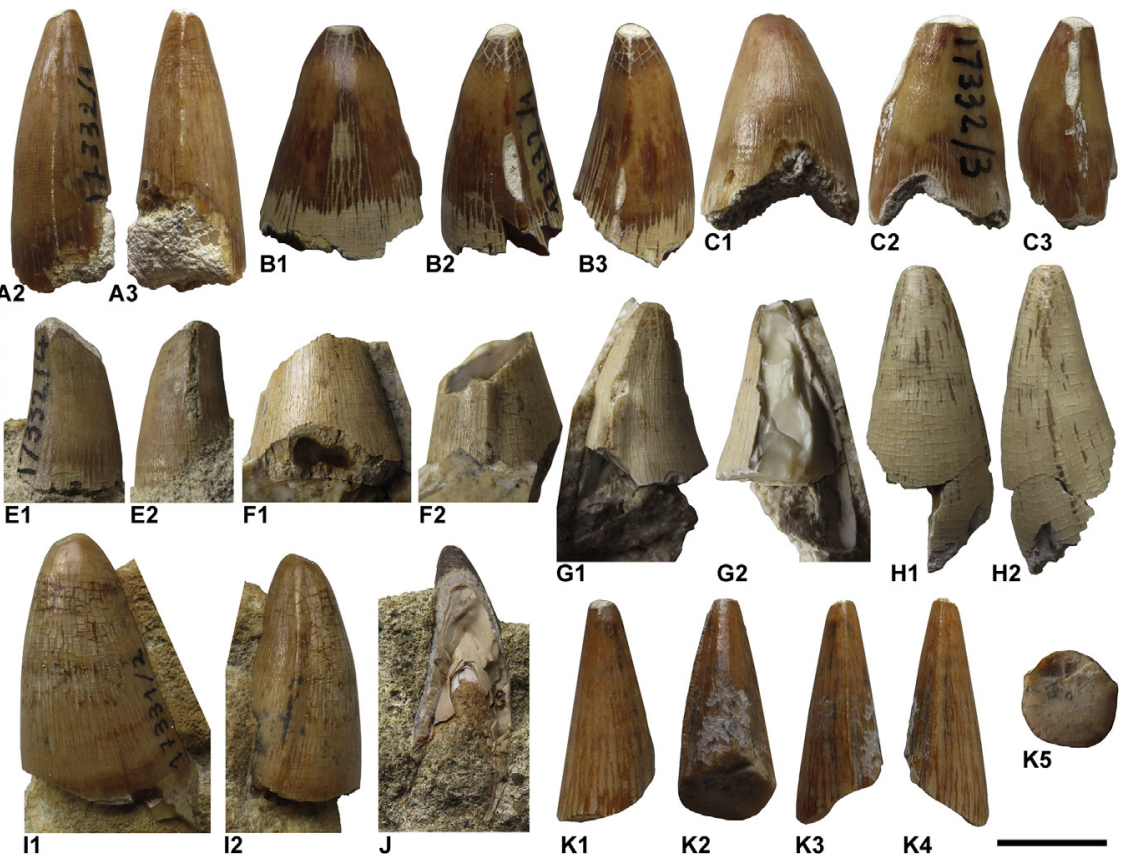

G1

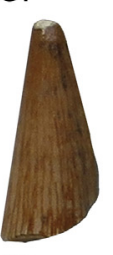

K1
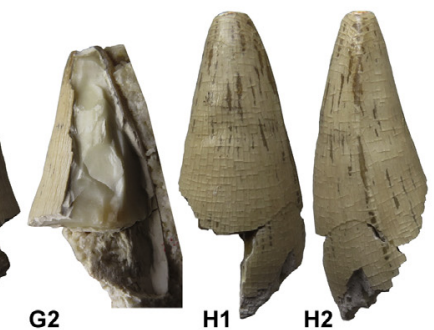

G2
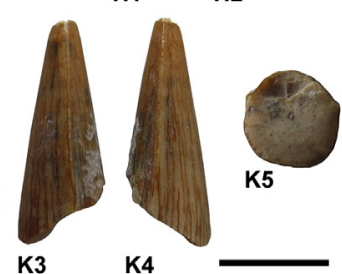

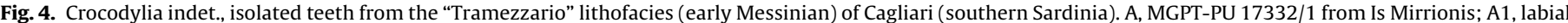

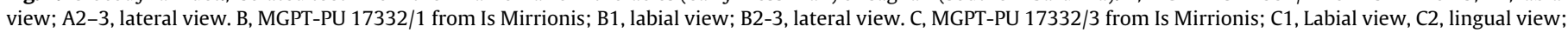

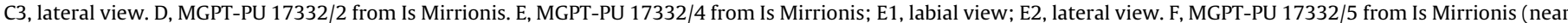

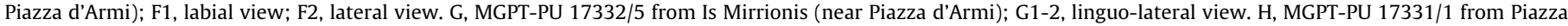

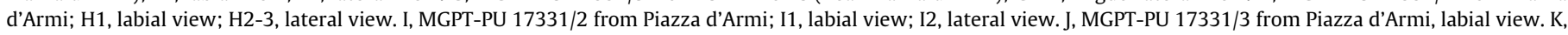

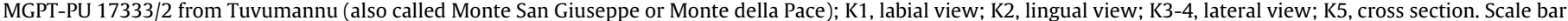
for A-C, E, F, H: $1 \mathrm{~cm}$; scale bar for D, K: $0.6 \mathrm{~cm}$; scale bar for G, I, J: $1.5 \mathrm{~cm}$.

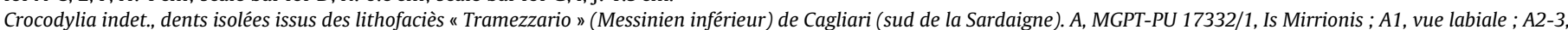

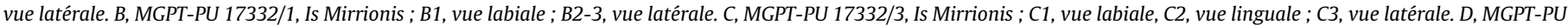

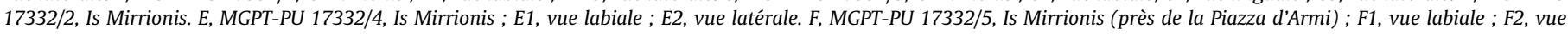

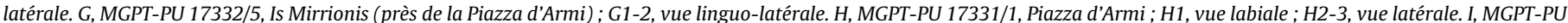

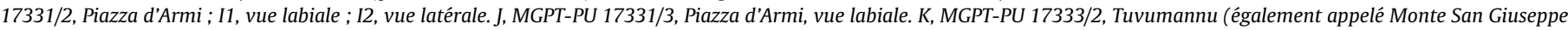

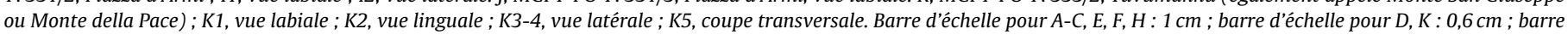
d'échelle pour $G, I, J: 1,5 \mathrm{~cm}$.

Description and remarks: The general morphology of the crocodylian teeth from Fiume Santo was already described in Abbazzi et al. (2008b) and the two isolated teeth figured here for the first time fit well with that description. The smallest (Fig. 5M; 22.10.1996, Area Ingresso Nord; Zona B), $11.0 \mathrm{~mm}$ tall, comes from the posterior section of a maxillary or dentary tooth row; it has well-marked mesiodistal carinae that are even more higlithened by a groove that runs parallel to them on both the lingual and labial surfaces. The largest (Fig. 5N; 23.10.1996, Area Ingresso Nord; A1/BD IV; terra di setacciatura) is massive and $22.1 \mathrm{~mm}$ tall, it was probably located in one of the largest alveoli of the tooth row.

\subsubsection{Locality}

Capo Frasca (Arbus, Monreale subregion, western Sardinia).

Age and geological setting: Capo San Marco Formation (early Messinian). The fossil was collected by Lovisato in a compact limestone.

Taxon: Crocodylia indet. (=Tomistoma sp. in Lovisato, 1892; Crocodylia indet. in Del Vecchio, 1921; Tomistoma calaritanus in Spano, 1985; Crocodylia indet. in Kotsakis et al., 2004; Tomistoma calaritanus in the original label of MGPT-PU).

Material: MGPT-PU 17335, one isolated tooth (Fig. 5L).

Description and remarks: This small, conical fragment can tentatively be considered a portion of the crown of a crocodylian tooth missing both the tip and the base.

\subsubsection{Localitiy}

Tuvumannu $=$ Monte San Giuseppe or Monte della Pace (Cagliari)

Age and geological setting: Calcari di Cagliari Formation (late Tortonian - early Messinian). The type material of Tomistoma calaritanum and several isolated crocodylian teeth were found in the carbonate succession of the Calcari di Cagliari Fm. (Gandolfi and Porcu, 1967; Cherchi, 1974), cropping out only in the Cagliari area. This succession is represented by three main lithofacies which are, from the bottom to top: "Pietra Cantone", "Tramezzario" and "Pietra Forte". Note that the names, informally adopted in the most recent official geological map (Barca et al., 2005), are derived from the names used by quarrymen (Georgalis et al., 2017). The bottom lithofacies ("Pietra Cantone") is represented by yellow marly-arenaceous limestone with common intense bioturbation. The "Tramezzario" (or "Tramezzara") is represented by calcarenites and marls with abundant bioclastic components. This lithofacies shows widespread phenomena of synsedimentary breccias, slumpings, erosional surfaces and faulting. The uppermost lithofacies ("Pietra Forte" or "Pietra di Bonaria") consists of massive coarse biostromal limestones (Barca et al., 2005). The carbonate succession of Cagliari is considered to be late Miocene in age (Kotsakis, 1985; Zoboli and Pillola, 2016b). The Tortonian-Messinian boundary is tentatively placed within the upper part of the "Pietra Cantone" (Georgalis et al., 2017).

Crocodyilian remains were collected in different localities of Cagliari since the beginning of the 19th Century: Tuvumannu, Piazza d'Armi, Is Mirrionis (= Mirioni in Gennari, 1868; Is Meriones 

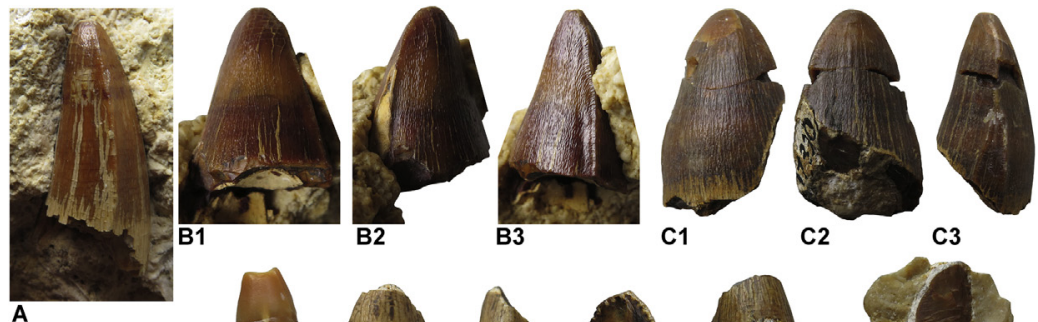

C2 C3

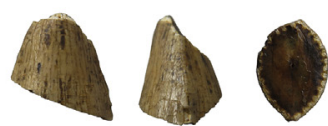

G1

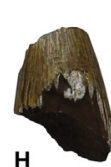

H

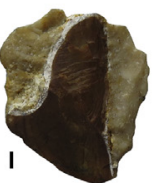

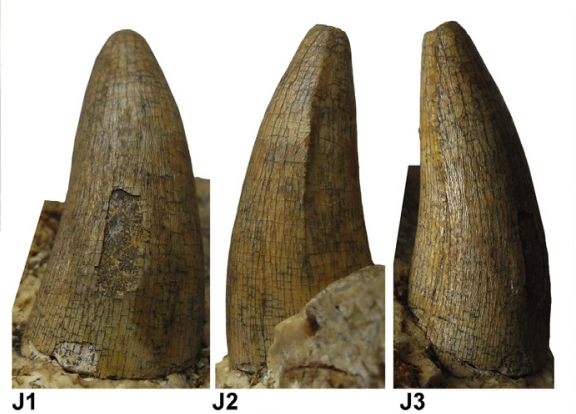

J2

$$
\text { J1 }
$$
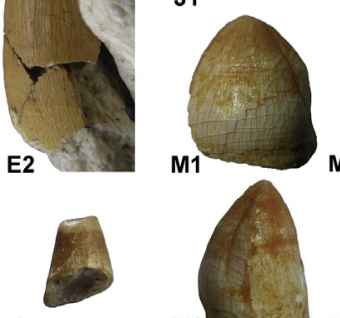

L
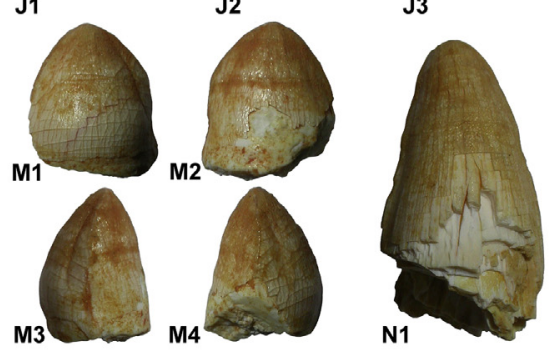
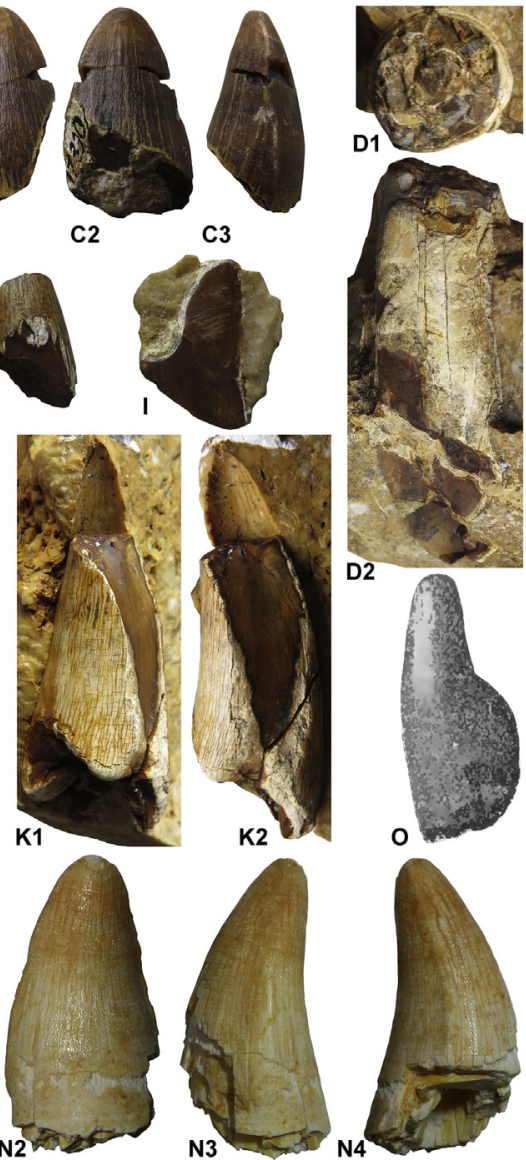

D2

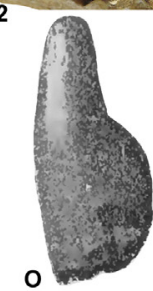

o

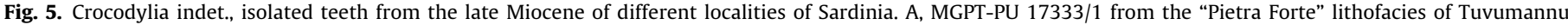

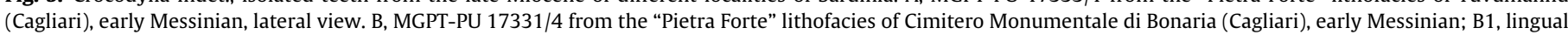

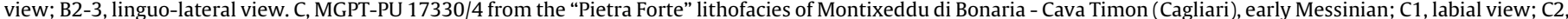

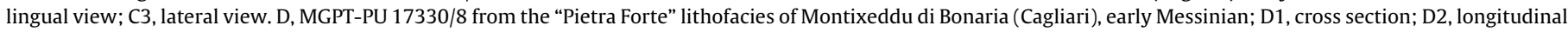

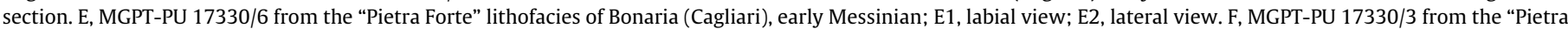

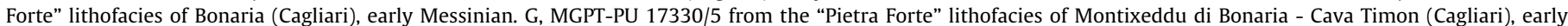

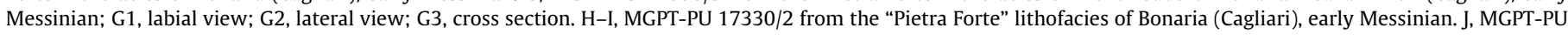

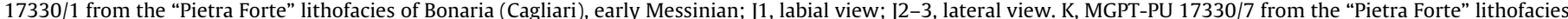

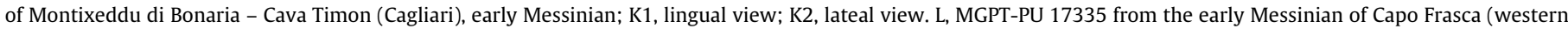

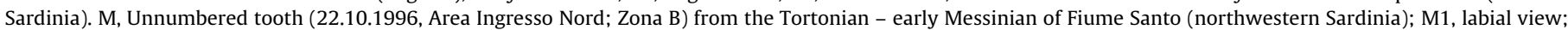

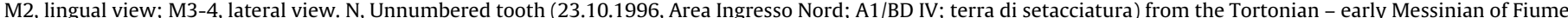

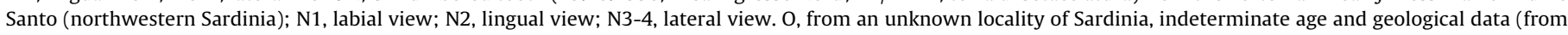
Del Vecchio, 1921). Scale bar for A-E, G-K, O: $1 \mathrm{~cm}$; scale bar for F: $0.5 \mathrm{~cm}$; scale bar for L: $0.3 \mathrm{~cm}$; scale bar for M, N: $0.7 \mathrm{~cm}$.

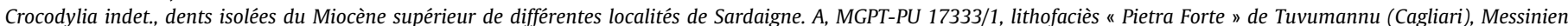

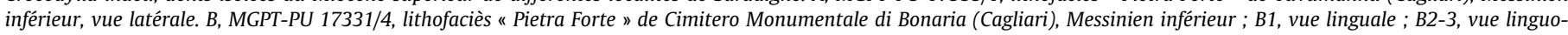

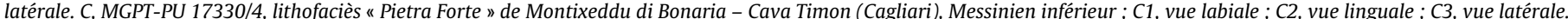

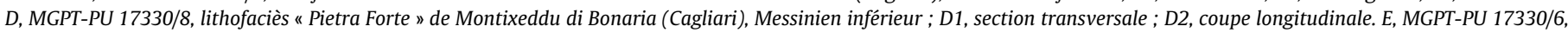

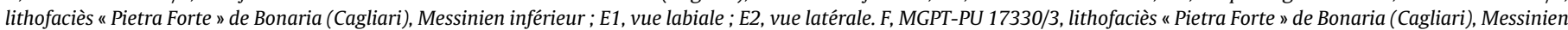

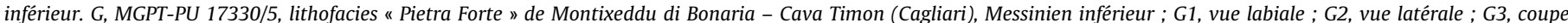

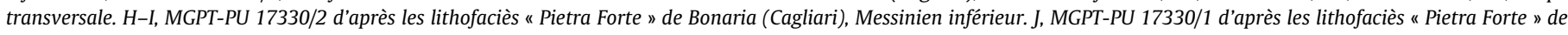

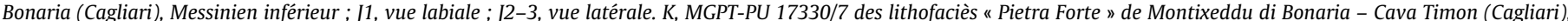

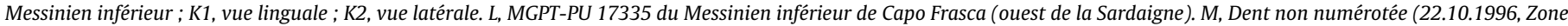

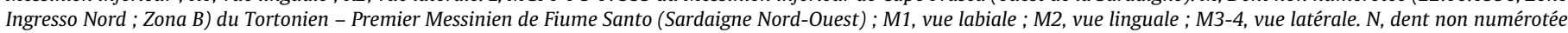

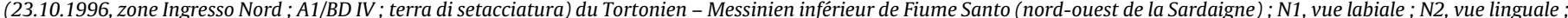

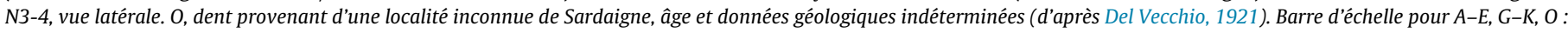
$1 \mathrm{~cm}$; barre d'échelle pour $F: 0,5 \mathrm{~cm}$; barre d'échelle pour $L: 0,3 \mathrm{~cm}$; barre d'échelle pour $M, N: 0,7 \mathrm{~cm}$.

in Capellini, 1890b; Is Miriones in Kotsakis et al., 2004), Bonaria, Cimitero Monumentale di Bonaria, Cava Timon - Montixeddu di Bonaria (Gennari, 1868; Capellini, 1890a, 1890b; Lovisato, 1892; Del Vecchio, 1921). The type of Tomistoma calaritanum was collected in the "Tramezzario" lithofacies cropping out in the Is Mirrionis neighbourhood (Piazza d'Armi). The associated reptile fauna from Is Mirrionis consists of the type material of the turtle Procyclanorbis sardus Portis, 1901, currently referred to an indeterminate pan-trionychine (Georgalis et al., 2017), and of other few isolated pan-trionychine remains (Comaschi Caria, 1958).

Taxon: Crocodylia indet. (= Crocodylia indet. in Capellini, 1890b, Lovisato, 1892; Del Vecchio, 1921; Crocodylus sp. in the original label of MGPT-PU).

Material: MGPT-PU 17333/2, from the "Tramezzario" lithofacies (Fig. 4K); MGPT-PU 17333/1, one isolated tooth from the "Pietra Forte" lithofacies (Fig. 5A). 

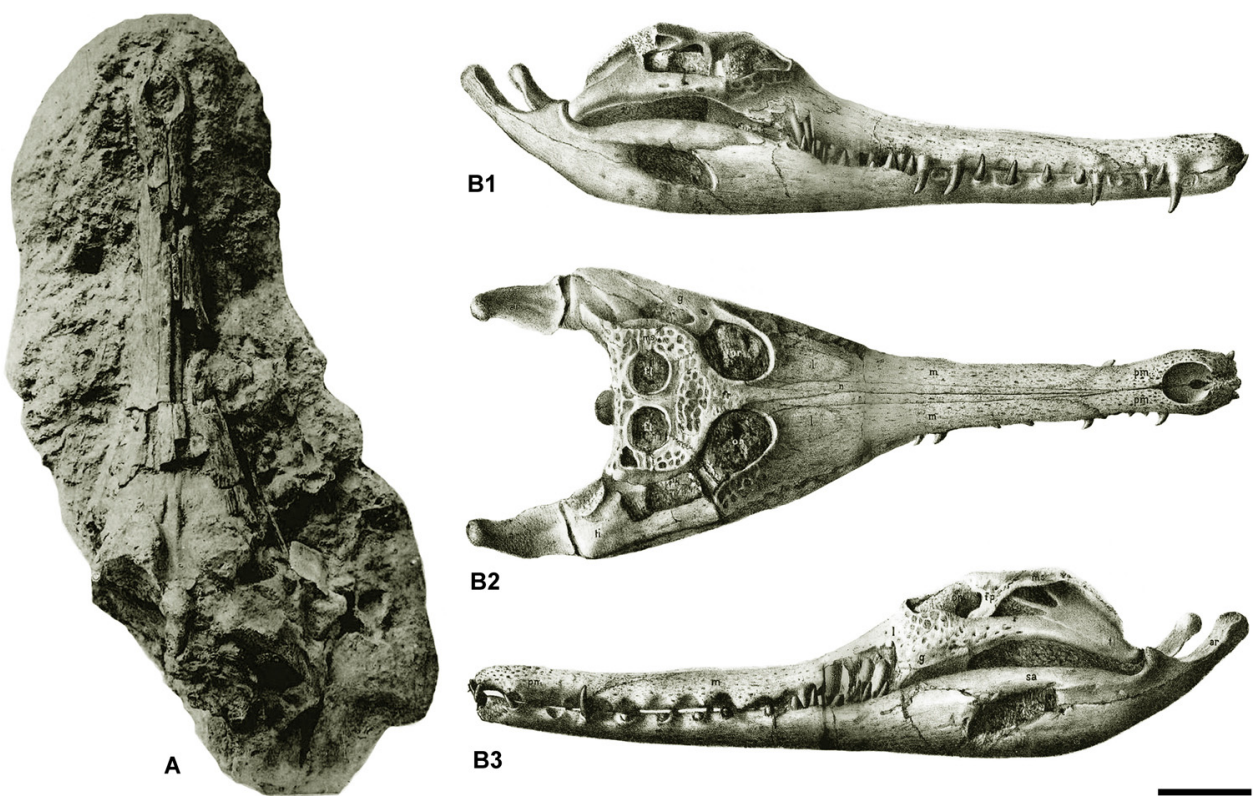

Fig. 6. The holotype skull of Tomistoma calaritanum Capellini, 1890 from the late Miocene of Piazza d'Armi, Cagliari (from the original plates of Capellini, $1890 \mathrm{~b}$ ). A, skull before the restoration in dorsal view. B, interpretative drawings of the restored skull; B1, right lateral view; B2, dorsal view; B3, left lateral view. Scale bar: $10 \mathrm{~cm}$. Crâne de Tomistoma calaritanum Capellini, 1890, holotype, issu du Miocène supérieur de Piazza d'Armi, Cagliari (d'après les planches originales de Capellini, 1890b). A, crâne en vue dorsale avant la restauration. $B$, dessins d'interprétation du crâne restauré; $B 1$, vue latérale droite ; $B 2$, vue dorsale ; $B 3$, vue latérale gauche. Barre d'échelle : $10 \mathrm{~cm}$.

Description and remarks: Lovisato (1892) reported a large size tooth from the "Tramezzario" of Monte San Giuseppe (=Tuvumannu) and referred it to a "true crocodile". Lovisato (1829) and Del Vecchio (1921) did not provide the figures of the material from Tuvumannu, therefore a sure correlation with the teeth housed in Turin is not possibile. MGPT-PU 17333/1 (Fig. 5A) is a partial crown, about $26 \mathrm{~mm}$ long, still embedded in a block of matrix whereas MGPT-PU 17333/2 (Fig. 4K) is the apex, $14.9 \mathrm{~mm}$ long, of a slender and thin tooth with sharp mesiodistal carinae delimiting a broad labial surface and a relatively small lingual surface (Fig. 4K5).

\subsubsection{Locality}

Bonaria, Montixeddu di Bonaria - Cava Timon (Cagliari).

Age and geologica setting: Calcari di Cagliari Formation (late Tortonian - early Messinian, Gandolfi and Porcu, 1967, see above).

Taxon: Crocodylia indet. (=Crocodylia indet. in Del Vecchio, 1921 and Kotsakis et al., 2004; Tomistoma calaritanus and "Crocodylus" sp. in the original label of MGPT-PU).

Material: All teeth are from the "Pietra Forte" lithofacies. MGPTPU 17330/1, one isolated tooth from Bonaria (Fig. 5J); MGPT-PU 17330/2, two incomplete teeth from Bonaria (Fig. 5H and I); MGPTPU 17330/3, one isolated tooth from Bonaria (Fig. 5F); MGPT-PU $17330 / 4$, one isolated tooth from Montixeddu di Bonaria - Cava Timon (Fig. 5C); MGPT-PU 17330/5, one isolated tooth from Montixeddu di Bonaria - Cava Timon (Fig. 5G); MGPT-PU 17330/6, one isolate tooth from Bonaria (Fig. 5E); MGPT-PU 17330/7, one isolated tooth from Montixeddu di Bonaria - Cava Timon (Fig. 5K). MGPT-PU 17330/8, one isolated tooth from Montixeddu di Bonaria (Fig. 5D).

Description and remarks: These isolated and incomplete teeth have a total length varying from $5.4 \mathrm{~mm}$ (MGPT-PU 17330/3) to about $42 \mathrm{~mm}$ (MGPT-PU 17330/7) or even to about $45 \mathrm{~mm}$ in the case of MGPT-PU 17330/8 whose state of preservation casts some doubt on its identity as crocodylian. As shown in Fig. 5, some of them are still embedded in a small block of matrix. Curiously, the only preserved mesiodistal carina of MGPT-PU 17330/4 bifurcates proximally (Fig. 5C3).

\subsubsection{Locality}

Cimitero Monumentale di Bonaria (Cagliari).

Age and geological setting: Calcari di Cagliari Formation (late Tortonian - early Messinian, Gandolfi and Porcu, 1967, see above).

Taxon: Crocodylia indet. (=Crocodylia indet. in Del Vecchio, 1921 and Kotsakis et al., 2004; Tomistoma calaritanus in the original label of MGPT-PU).

Material: MGPT-PU 17331/4, one isolated tooth from the "Pietra Forte" lithofacies (Fig. 5B).

Description and remarks: the exposed portion of the parlty embedded crown MGPT-PU 17331/4 is very well-preserved and shows the wrinkles of the enamel surface extending onto the mesiodistal carinae; considering also the basal portion of the crown that is only minimally preserved, the remain is $23 \mathrm{~mm}$ long.

\subsubsection{Locality}

Is Mirrionis-Piazza d'Armi (Cagliari). The original labels of the material housed at MGPT-PU indicate two different localities: "Is Mirrionis" and "Piazza d'Armi". However, Piazza d'Armi is actually included in the Is Mirrionis neighborhood, therefore, we prefer to group together all of the isolated crocodylian teeth from these toponyms.

Age and geological setting: Calcari di Cagliari Formation (late Tortonian - early Messinian, Gandolfi and Porcu, 1967, see above).

Taxa: Crocodylia indet. (= Crocodylia indet. in Del Vecchio, 1923 and Kotsakis et al., 2004; Tomistoma calaritanus in the original label of MGPT-PU).

Material: all fossils are from the "Tramezzario" lithofacies. MGPT-PU 17332/1, two isolated teeth (Fig. 4A and B); MGPT-PU $17332 / 2$, one isolated tooth (Fig. 4D); MGPT-PU 17332/3, one isolated tooth (Fig. 4C); MGPT-PU 17332/4, one isolated tooth (Fig. 4E); MGPT-PU 17332/5, two incomplete tooth (Fig. 4F and G). MGPT-PU $17331 / 1$, one isolated tooth (Fig. 4H); MGPT-PU 17331/2, one isolated tooth (Fig. 4I); MGPT-PU 17331/3, one isolated tooth (Fig. 4J).

Description and remarks: Is Mirrionis: the sample of isolated teeth from Is Mirrionis is characterized by a relatively small size, being the smallest (MGPT-PU 17332/2) just $9 \mathrm{~mm}$ long and the largest (one of the two teeth accessioned under the number 

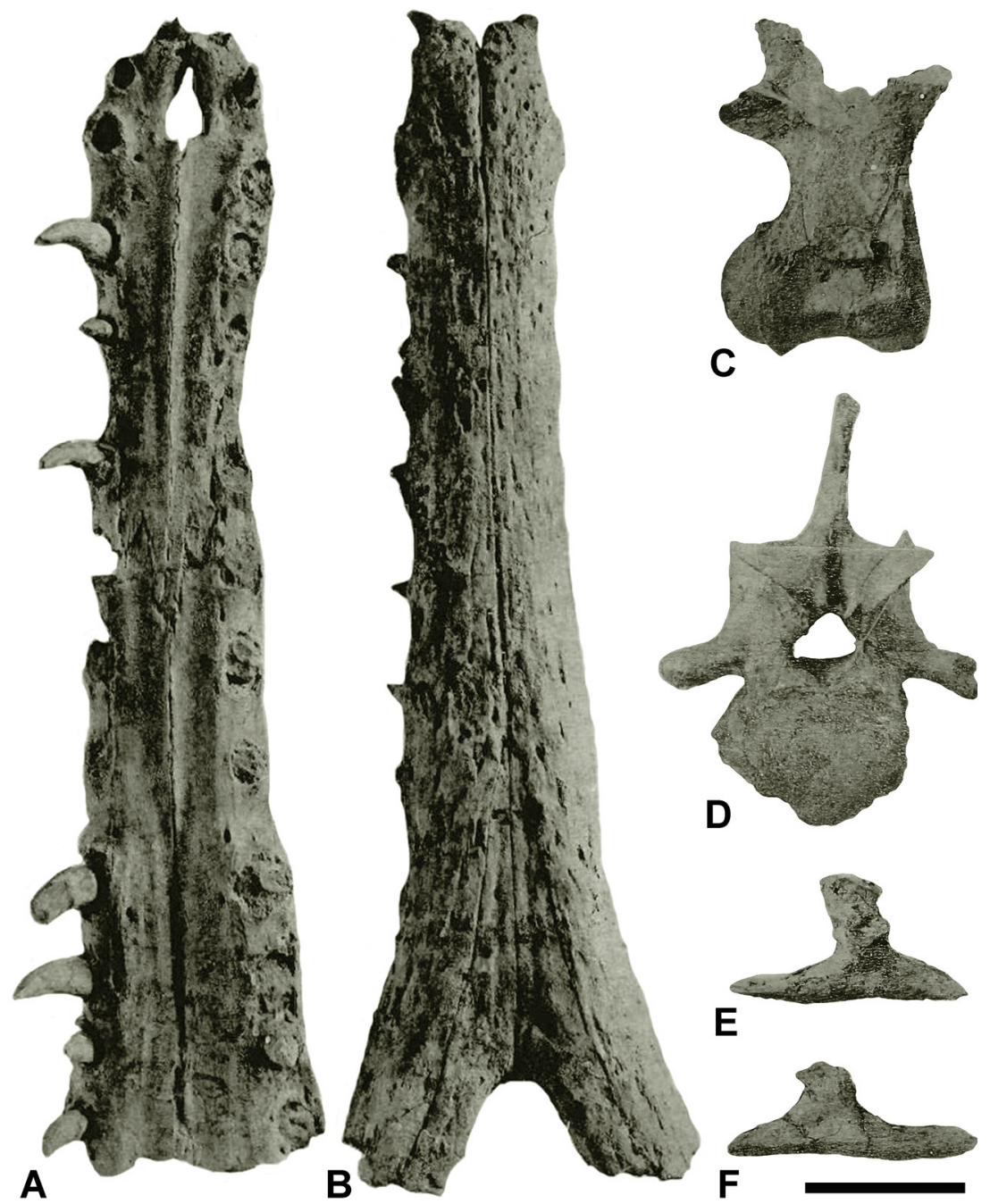

E

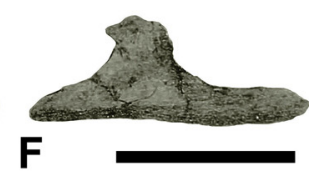

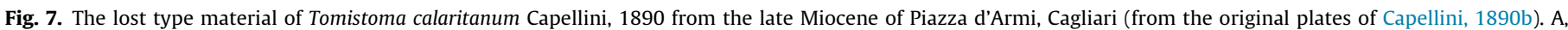

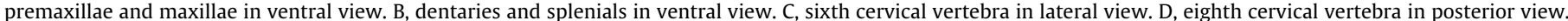
E-F, cervical ribs. Scale bar: $5 \mathrm{~cm}$.

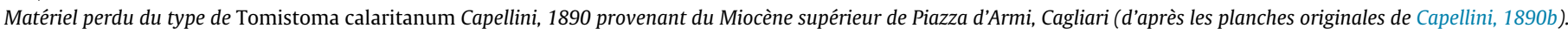

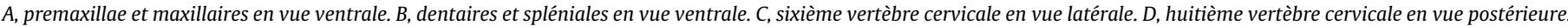
$E-F$, côtes cervicales. Barre d'échelle : $5 \mathrm{~cm}$.

MGPT-PU 17332/5) about $28 \mathrm{~mm}$ long (including the portion that is parlty hidden). Some of the teeth are still embedded in a whitish matrix. Piazza d'Armi: MGPT-PU 17331/1 (Fig. 4H) is an isolated, fragmentary crown, $27.2 \mathrm{~mm}$ long, whereas MGPT-PU 17331/2 (Fig. 4I) is a large, massive crown, about $36 \mathrm{~mm}$ long; the latter is still embedded in the matrix and shows prominent mesiodistal carinae. Also MGPT-PU 17331/3 (Fig. 4J) is still embedded in a small block but it is heavily damaged; it is an elongated tooth with a total length of approximately $39 \mathrm{~mm}$. These isolated teeth, despite the absence of diagnostic characters, may belong to the tomistomine crocodylian described below.

\subsubsection{Locality}

Piazza d'Armi (Cagliari).

Age and geological setting: Calcari di Cagliari Formation (late Tortonian - early Messinian, Gandolfi and Porcu, 1967, see above).

Taxon: Tomistoma calaritanum Capellini, 1890 (Fig. 6).

Material: one incomplete cranium (MDLCA 148) (Fig. 9B and C), eight incomplete osteoderms (MDLCA 14401) (Fig. 8A2, E-G, I, L3, M3, N2), casts of the restored cranium (Fig. 9A) and six osteoderms (Fig. 8D, H2, J2, K2, L2, M2 [collection of Dipartimento di Scienze Chimiche e Geologiche of the University of Cagliari; note that these casts are a copy of the original casts housed in the Museo Geologico G. Capellini of Bologna]). Part of the cranium (Fig. 7A andB), some osteoderms (Fig. 8B and C), cervical vertebrae (Fig. 7C and D) and cervical ribs (Fig. 7E and F) were lost or destroyed during the Second World War.

The holotype of Tomistoma calaritanum Capellini, 1890: The comparison of the descriptions and illustrations provided by Capellini (1890b) with the current state of preservation of MDLCA 148 (Fig. 9B) clearly indicates that most of the skeletal elements and the morphological information they provided is now lost. As emphasized by Capellini (1890b, p. 514), the figures in his publication do not clearly identify what is represented by plaster versus real bones. However, the color of the plaster cast of the original restored skull (Fig. 9A) represents the only way to discriminate the real extent of the restoration work performed by Capellini. The main skeletal elements still preserved are the posterior region of both the maxillae, part of the nasals and quadratojugals (Fig. 10). The lower jaw still preserves the posterior region of the dentaries, part of the surangular and angular (the latter only on the left side). The surface of the block preserves the morphology of the inner surface of part of the elements of the dorsal area (the posterior area of the nasals and maxillae in particular). Moreover, very 


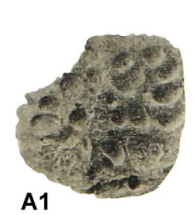

A1

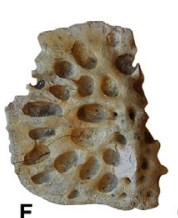

A2
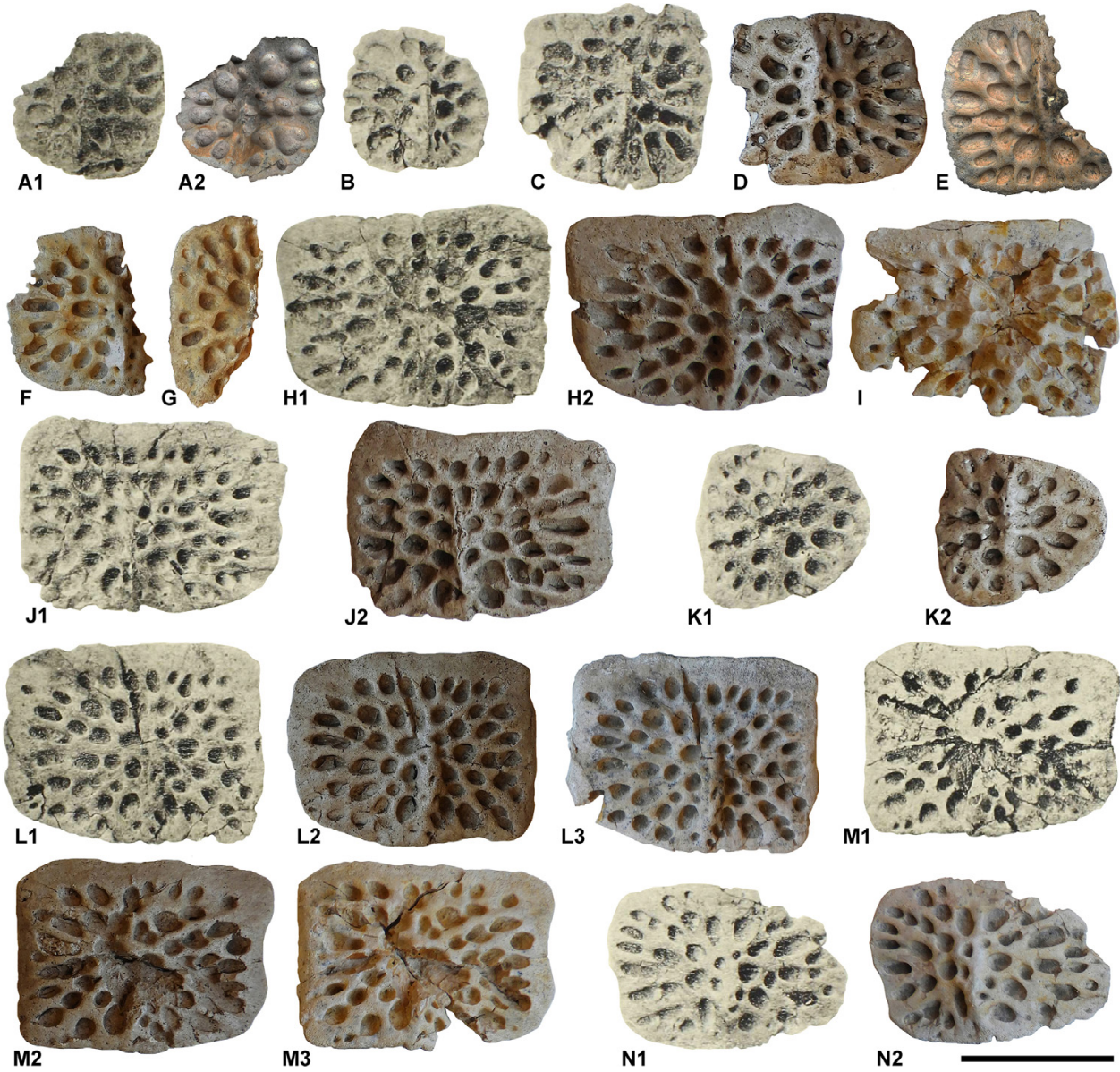

$\mathrm{K} 2$
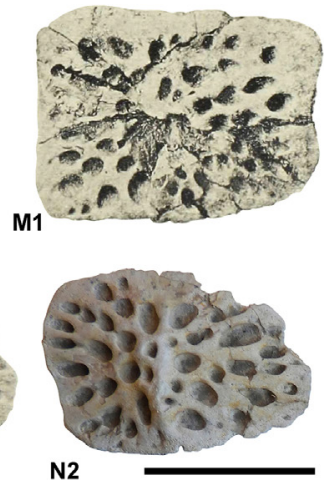

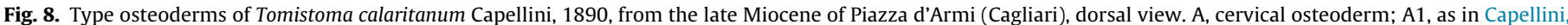

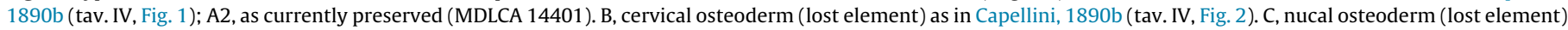

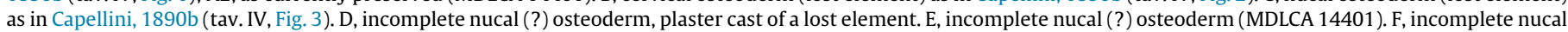

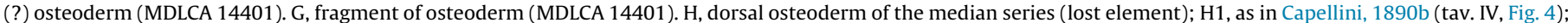

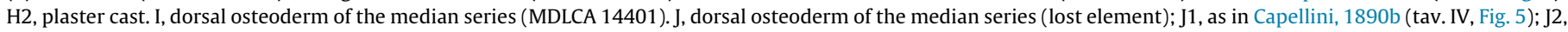

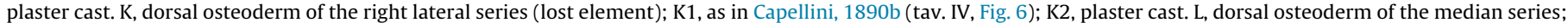

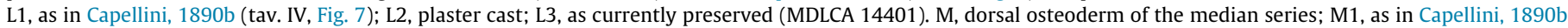

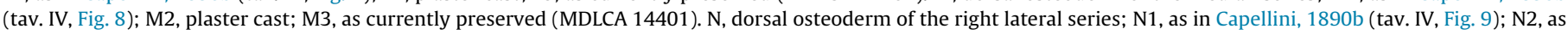
currently preserved (MDLCA 14401). Scale bar: $5 \mathrm{~cm}$.

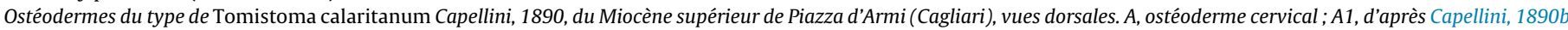

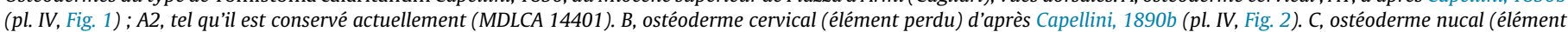

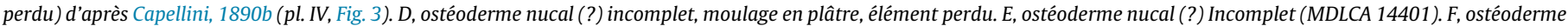

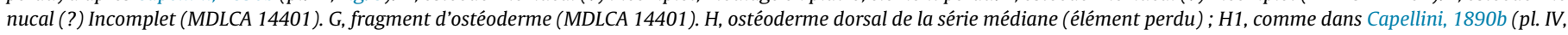

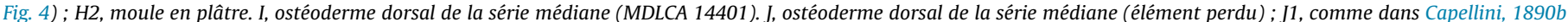

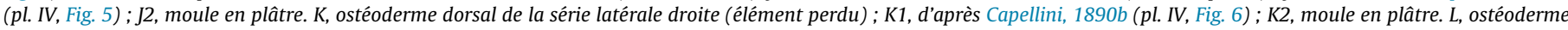

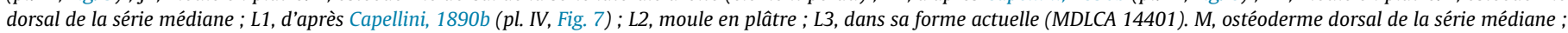

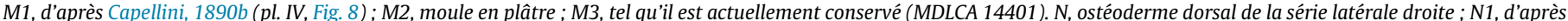
Capellini, $1890 \mathrm{~b}$ (pl. IV, Fig. 9) ; N2, tel qu'il est actuellement conservé (MDLCA 14401). Barre d'échelle : $5 \mathrm{~cm}$.

fragmentary skeletal elements in section are preserved on the anterior, posterodorsal, and posterior surfaces of the block. They do not provide relevant morphological information and in many cases they cannot be identified with certainty.

The currently available eight osteoderms, collectively accessioned as MDLCA 14401 (Fig. 8), are variably incomplete but share the same external ornamentation characterized by relatively few and very large pits. The anterior smooth surface is anteroposteriorly short and the longitudinal keel is rather low. The largest of the osteoderms (plaster cast Fig. 8H2) is $68 \mathrm{~mm}$ wide and $92 \mathrm{~mm}$ long. Capellini (1890b) reported the presence of about twenty osteoderms, but figured only nine specimens (the original photographs by Capellini are here shown in Fig. 8A1, B, C, H1, J1, K1, L1, M1, N1). Five of these nine osteoderms figured by Capellini (1890b) are currently lost (Fig. 8B, C, H1, J1, K1), but the plaster casts of three specimens are still available (Fig. 8H2, J2, K2). Moreover, four incomplete osteoderms originally not figured by Capellini (1890b) are currently available (Fig. 8E, F, G, I) and the plaster cast of a lost specimen is available (Fig. 8D).

Capellini (1890b) listed and briefly described several, mostly incomplete vertebrae (fragments of the I-II cervical vertebrae, the III, IV, VI, VIII, IX cervical vertebrae, fragments of the first dorsal vertebrae, one lumbar vertebra and one caudal vertebra) but figured only two of them (tav IV, Figs. 10 and 11 in Capellini, 1890b; Fig. 9C, D in this paper). In addition, Capellini (1890b) figured two cervical ribs (tav. IV, Figs. 12 and 13 in Capellini, 1890b; Fig. 7E, F in this paper). All vertebrae and cervical ribs are currently lost.

Remarks and nomenclatural issues: Gennari (1868) conditionally proposed the name Croc. Caralitanus (=Crocodylus caralitanus) for the taxon from Piazza d'Armi. Since the paper was published before 1961, according to the Article 11.5.1 of ICZN (1999) the name is not to be excluded just because of the conditional context in 


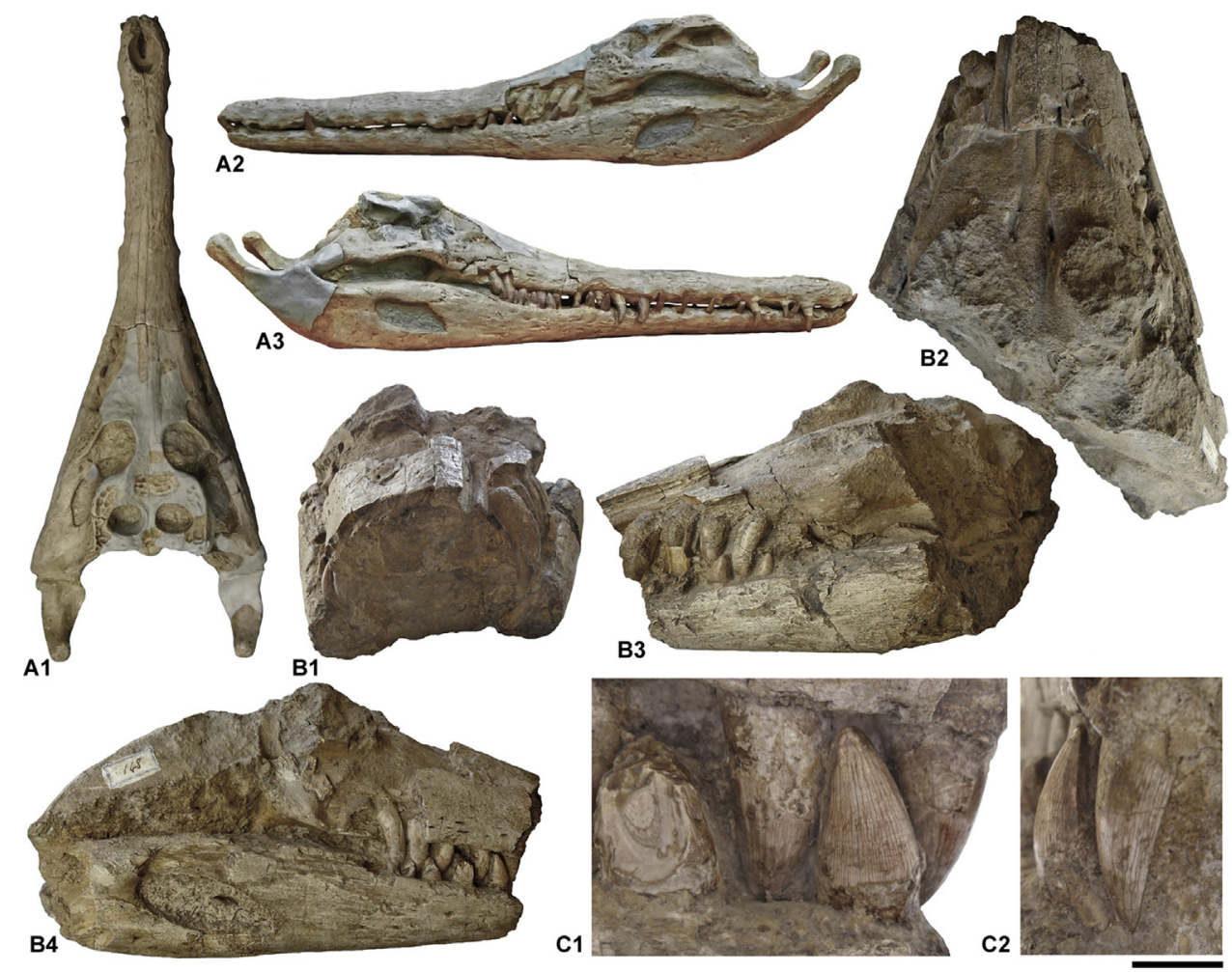

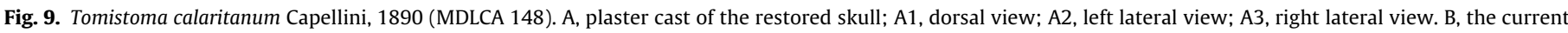

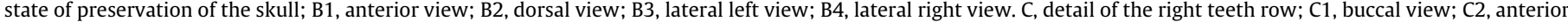
view. Scale bar for A: $10 \mathrm{~cm}$, scale bar for B: $5 \mathrm{~cm}$, scale bar for C: $1 \mathrm{~cm}$.

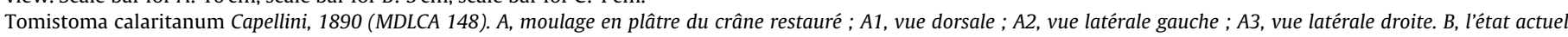

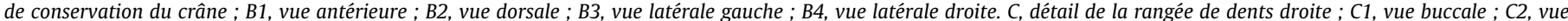
antérieure. Barre d'échelle pour $A: 10 \mathrm{~cm}$, barre d'échelle pour $B: 5 \mathrm{~cm}$, barre d'échelle pour $C: 1 \mathrm{~cm}$.

which it was proposed. It is actually an available name because Gennari (1868: 128-129) provided a brief description focusing on the elongated snout, on its length versus the length of the rest of skull, and on the number $(24 / 20=84)$, the disposition, and the shape of the teeth that resemble Gavialis gangeticus and Crocodylus acutus. Few decades later, Capellini (1890a,b) clarified that the specimen was actually a tomistomine crocodylian.

Regardless of the generic referral, even if the specific epitheh Crocodylus caralitanus Gennari, 1868 is available, it is here proposed a reversal of precedence in favor of Tomistoma calaritanus Capellini, 1890 because:

- the senior synonym was never used after 1899 (article 23.9.1.1; ICZN, 1999) (apparently it was used only by Gennari in 1868; and then mentioned by Capellini, 1890, as the name written on the tag of the specimen by Gennari himself), and;

- the junior synonym has been used in the last 50 years in at least in 25 works (sometimes as T. calaritanum, see below; Kotsakis and Palombo, 1979; Esu and Kotsakis, 1983; Spano, 1985; Comaschi Caria, 1986; Antunes and Ginsburg, 1989; Rossmann et al., 1996; Brochu, 1997, 2001; Crespo, 2001; Kotsakis et al., 2004; Weems, 2006; Piras et al., 2007; Mas and Antunes, 2008; Delfino, 2010; Delfino and Ragazzini, 2010; Fanti, 2010; Gerali, 2012, 2014; Delfino and Rossi, 2013; Delfino and Rook, 2008b; Abate and Fanti, 2014; Delfino et al., 2014; Jouve et al., 2014; Georgalis et al.,
2016, 2017; Zoboli and Pillola, 2016b) published by at least 10 authors in a time span encompassing more than 10 years (article 23.9.1.2; ICZN, 1999).

Therefore, it is here formally proposed to maintain the prevailing name Tomistoma calaritanus Capellini, 1890 that becomes a nomen protectum, whereas Crocodylus caralitanus Gennari (1868) is a nomen oblitum. However, worth noting is that Kotsakis et al. (2004) and Piras et al. (2007), considering that the gender of the epithet Tomistoma is neutral, correctly modified the specific epithet in Tomistoma calaritanum. A reassessment of the validity of this species will be the subject of another project that requires a broad comparison of the holotype with several other extinct tomistomes that were diagnosed and named in the past.

\subsection{Unknown age}

\subsubsection{Locality}

unknown.

Age and geological setting: unknown.

Taxon: Crocodylia indet. (=Tomistoma calaritanus in Del Vecchio, 1921).

Material: one isolated tooth figured by Del Vecchio, 1921 (Fig. 50). The specimen is not present in the collection of MDLCA and MGPT-PU. 


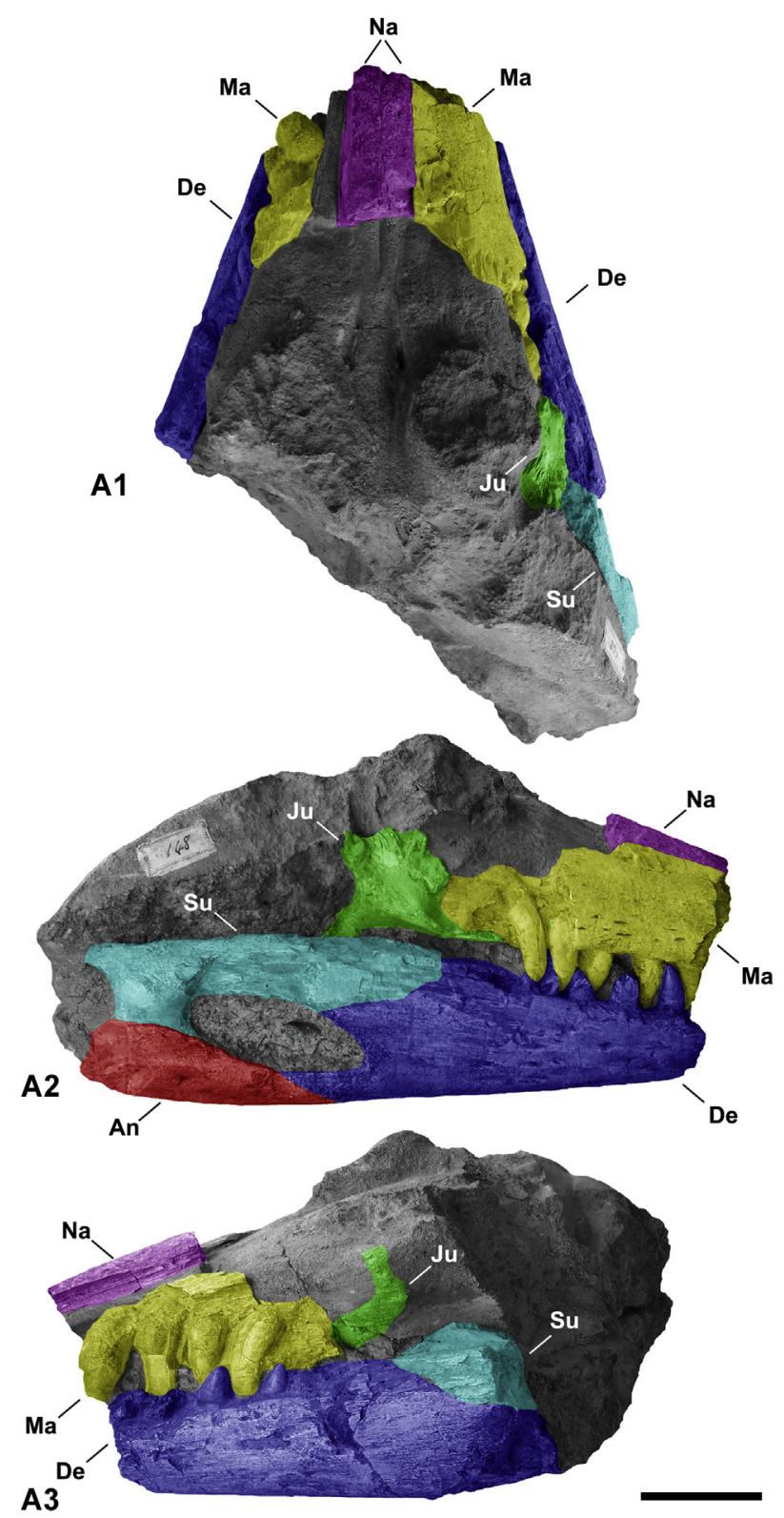

Fig. 10. Tomistoma calaritanum Capellini, 1890 (MDLCA 148), preserved skeletal elements of the skull. A1, dorsal view; A2, right lateral view; A3, left lateral view. Abbreviations: An, angular; Su, surangular; De, dentary; Ju, jugal; Ma, maxilla; Na, nasal. Scale bar: $5 \mathrm{~cm}$.

Tomistoma calaritanum Capellini, 1890 (MDLCA 148), éléments squelettiques préservés du crâne. A1, vue dorsale; $A 2$, vue latérale droite ; $A 3$, vue latérale gauche. Abréviations : An, angulaire ; $\mathrm{Su}$, surangulaire ; De, dentaire ; Ju, jugal ; Ma, maxillaire ; Na, nasale. Barre d'échelle : $5 \mathrm{~cm}$.

\section{Conclusions}

The crocodylian remains from most of the Sardinian localities are exclusively represented by isolated teeth that are not diagnostic beyond the ordinal level despite their original referral (in museum labels or published papers) to Crocodylus, Diplocynodon or Tomistoma. The relevant exception is represented by the remains from Piazza d'Armi in Cagliari referred by Gennari (1868) to the new species Crocodylus caralitanus and later on by Capellini (1890a, b) to Tomistoma calaritanus. Here we provide evidence for the reversal of precedence in favor of the latter name, that, however, being Tomistoma neutral, should be Tomistoma calaritanum. The holotype was a relatively well-preserved skull (and associated osteoderms and vertebrae) in origin but was damaged during WWII and then partly lost. The only other informative material from Sardinia consists of some osteoderms and other postcranial elements that are now apparently lost; it comes from the late Burdigalian of La Crucca and can be tentatively referred to a tomistomine. Since extinct tomistomines are generally found in coastal environments and therefore they were likely able to easily disperse, the validity of Tomistoma calaritanum should be reassessed in the context of a broad revision of the Tethysean tomistomines.

\section{Disclosure of interest}

The authors declare that they have no competing interest.

\section{Acknowledgements}

Edoardo Razzetti helped us in disentangling the nomenclatural issue of Tomistoma caralitanus. We are grateful to Daniele Ormezzano for his assistance during our analysis of the material housed at MGPT-PU. Fig. 5M and N courtesy of Nella Tuveri, Soprintendenza Archeologia, belle arti e paesaggio per le province di Sassari e Nuoro. Figs. 2, 8 and 9 courtesy of MDLCA. Wilma Wessels and Hans de Bruijn (UU) are thanked for the extended loan of material from Oschiri. We gratefully acknowledge the Sardinia Regional Government for the financial support to the Ph.D scholarship to DZ (P.O.R. Sardegna F.S.E. Operational Programme of the Autonomous Region of Sardinia, European Social Fund 2007-2013 - Axis IV Human Resources, Objective 1.3, Line of Activity 1.3.1.). The research was supported by the Università di Cagliari CAR Project, "Paleobiodiversità: strumento di base in biostratigrafia, in paleoecologia e nella valorizzazione dei beni culturali Geo-Paleontologici" led by GLP. Project supported by Fondi di Ateneo dell'Università di Torino (2016-2017), Generalitat de Catalunya (CERCA Program), and Spanish Agencia Estatal de Investigación (CGL2016-76431-P, AEI/FEDER, EU) to MD. We would like to thank reviewers Angela Buscalioni and Jérémy Martin for comments that greatly improved the quality of the manuscript.

\section{References}

Abate, D., Fanti, F., 2014. La valorizzazione digitale del Museo Geologico Giovanni Capellini di Bologna. Archeomatica 5, 6-9.

Abbazzi, A., Angelone, C., Arca, M., Barisone, G., Bedetti, C., Delfino, M., Kotsakis, T. Marcolini, F., Palombo, M.R., Pavia, M., Piras, P., Rook, L., Torre, D., Tuveri, C., Valli, A.M.F., Wilkens, B., 2004. Plio-Pleistocene fossil vertebrates of Monte Tuttavista (Orosei, E Sardinia, Italy), an overview. Rivista Italiana Paleontologia Stratigrafia 110, 681-706.

Abbazzi, L., Carboni, S., Delfino, M., Gallai, G., Lecca, L., Rook, L., 2008a. Fossil vertebrates (Mammalia and Reptilia) from Capo Mannu (Late Pliocene, Western Sardinia, Italy) with description of a new Testudo (Chelonii, Testudinidae) species. Rivista Italiana di Paleontologia e Stratigrafia 114, 119-132.

Abbazzi, A., Delfino, M., Gallai, G., Trebini, L., Rook, L., 2008b. New data on the vertebrate assemblage of Fiume Santo (North-West Sardinia Italy) and overview on the Late Miocene Tusco-Sardinian palaeobioprovince. Palaeontology 52, 251-425.

Antunes, M.T., Ginsburg, L., 1989. Les Crocodiliens desfaluns miocènes de l'Anjou. Bulletin du Muséum national d'histoire naturelle Paris 11, 79-99.

Azzaroli, A., 1983. Biogeografia dei mammiferi della Sardegna. Journal of Integrative Biogeography 8, 35-52.

Azzaroli, A., Guazzone, G., 1979. Terrestrial mammals and land connections in the Mediterranean before and during the Messinian. Palaeogeography, Palaeoclimatology, Palaeoecology 29, 155-167

Barca, S., Melis, E., Annino, E., Cincotti, F., Ulzega, A., Orrù, P., Pintus, C., 2005. Note Illustrative della Carta Geologica d'Italia alla scala 1:50.000. In: Foglio 557 "Cagliari". Servizio Geologico d'Italia, Regione Autonoma della Sardegna, S.EL.CA, Firenze.

Brochu, C.A., 1997. Fossils, morphology, divergence timing, and the phylogenetic relationships of Gavialis. Systematic Biology 46, 479-522.

Brochu, C.A., 2001. Congruence between physiology, phylogenetics, and the fossil record on crocodylian historical biogeography. In: Grigg, G., Seebacher, F., Franklin, C.E. (Eds.), Crocodilian biology and evolution. , pp. 9-28. 
Casanovas-Vilar, I., van Dam, J.A., Trebini, L., Rook, L., 2011. The rodents from the Late Miocene Oreopithecus-bearing site of Fiume Santo (Sardinia, Italy). Geobios 44, 173-187.

Capellini, G., 1890a. Sul coccodrilliano gavialoide (Tomistoma calaritanus) scoperto nella collina di Cagliari nel 1868. Rendiconti della Reale Accademia dei Lincei 4, 149-151.

Capellini, G., 1890b. Sul coccodrilliano garialoide (Tomistoma calaritanus) scoperto nella collina di Cagliari nel MDCCCLXVIII. Atti della Reale Accademia Lincei, Memorie della Classe di Scienze Fisiche. Matematiche e Naturali 6, 507-533.

Cherchi, A., 1974. Appunti biostratigrafici sul Miocene della Sardegna (Italia), actes V congrès du Néogene Méditerranée Lyon 1971, 78. Mémoire du Bureau de Recherches Géologiques et Minières, pp. 433-445.

Cherchi, A., 1985. Micropaleontological researches in Sardinia., pp. 1-338 [Guide Book - 19th European Micropaleontological Colloquium Sardinia].

Chesi, F., 2008. Il registro fossile italiano dei cheloni. Universitàdi Firenze, Florence [PhD dissertation. Unpublished].

Chesi, F., Delfino, M., Abbazzi, L., Carboni, S., Lecca, L., Rook, L., 2007. New fossil vertebrate remains from San Giovanni di Sinis (Late Pleistocene, Sardinia): the last Mauremys (Reptilia, Testudines) in the Central Mediterranean. Rivista Italiana di Paleontologia e Stratigrafia 113, 287-297.

Chesi, F., Delfino, M., Pillola, G.L., Rook, L., Villani, M., 2008. A Pleistocene European pond turtle from Sardinia. In: Corti, C. (Ed.), Herpetologia Sardiniae. Societas Herpetologica Italica, 8. "Le Scienze”, Edizioni Belvedere, p. 504.

Comaschi Caria, I., 1958. Nuovi resti di cheloni nel Miocene della Sardegna. Bollettino della Società Geologica Italiana 77, 1-11.

Comaschi Caria, I., 1986. Animali e piante fossili della Sardegna. (Terza edizioneampliata e con un guida breve allo studio della Paleontologia). Edizioni dellaTorre, Cagliari.

Crespo, E.G., 2001. Paleo-herpetofauna de Portugal. Publicaçoes Avulsas (Museu Bocage. Museu Nacional de Història Natural, 2 Série, 7), Lisboa.

De Bruijn, H., Rümke, C.G., 1974. On a peculiar mammalian association from the Miocene of Oschiri (Sardinia). Proceedings of the Koninklijke Nederlandse Akademie Van Wetenschappen Series B, 77., pp. 46-79.

Delfino, M., 2010. Fossil tomistomines from an Italian perspective. In: Kobayashi, Y., Eguchi, T. (Eds.), The giant extinct animal, Machikane crocodile: the crocodiles that survived from the age of dinosaurs. The Museum of Osaka University, Osaka, Japan, pp. 76-77.

Delfino, M., Böhme, M., Rook, L., 2007. First European evidence for transcontinental dispersal of Crocodylus (late Neogene of southern Italy). Zoological Journal of Linnean Society 149, 239-307.

Delfino, M., Kotsakis, T., Arca, M., Tuveri, C., Pitruzzella, G., Rook, L., 2008. Agamid lizards from the Plio-Pleistocene of Sardinia (Italy) and an overview of the European fossil record of the family. Geodiversitas 30, 641-656.

Delfino, M., Pitruzzella, G., Bailon, S., 2011. The Late Pliocene amphibians and reptiles from "Capo Mannu D1 Local Fauna” (Mandriola, Sardinia, Italy). Geodiversitas 33, 357-382.

Delfino, M., Ragazzini, S., 2010. Fossil amphibians and reptiles from Abruzzi and Molise: old data and new evidences. Programma e Riassunti del VIII Congresso Nazionale Societas Herpetologica Italica, VIII Congresso Nazionale Societas Herpetologica Italica Chieti., pp. 81-82.

Delfino, M., Rossi, M.A., 2013. Fossil crocodylid remains from Scontrone (Tortonian, Southern Italy) and the Late Neogene Mediterranean biogeography of crocodylians. Geobios 46, 25-31.

Delfino, M., Rook, L., 2008a. The fossil amphibians and reptiles of Sardinia: a summary. In: Corti, C. (Ed.), Herpetologia Sardiniae. Societas Herpetologica Italica, 8. "Le Scienze", Edizioni Belvedere, p. 504.

Delfino, M., Rook, L., 2008b. African crocodylians in the Late Neogene of Europe. A revision of Crocodylus bambolii Ristori, 1890. Journal of Paleontology 82, 336-343.

Delfino, M., Zoboli, D., Carnevale, G., Pillola, G.L., 2014. The rediscovered holotype of Palaeopython sardus Portis, 1901 from the Miocene of Sardinia belongs to a fish, not a snake. Bollettino della Società Paleontologica Italiana 53, 89-92.

Delussu, F., 2007. Produzione e consumo dei prodotti animali nell'ambito dell'economia di Turris Libisonis (Porto Torres, Sassari) in età imperiale. In: Fiore, I., Malerba, G., Chilardi, S. (Eds.), Atti del 3 (Convegno Nazionale di Archeozoologia. Siracusa 3-5 novembre 2000. Studi di Paletnologia II (2005). Collana del Bullettino di Paletnologia Italiana, Istituto Poligrafico della Zecca, p. 517.

Del Vecchio, C., 1921. Su alcuni denti di Tomistoma (Crocodilia) dell'Oligocene di Visone presso Acqui. Atti della Società Italiana di Scienze Naturali 60, 419-431.

Esu, D., Kotsakis, T., 1983. Les vertébrés et les mollusques continentaux du Tertiaire de la Sardaigne : paléobiogéographie et biostratigraphie. Geologia Romana 22, $177-206$.

Fanti, F., 2010. Life and ideas of Giovanni Capellini (1833-1922): a palaeontological revolution in Italy. In: Moody, R.T.J., Buffetaut, E., Naish, D., Martill, D.M. (Eds.) Dinosaurs and other extinct saurians: a historical perspective, 343. Geological Society, London, Special Publications, pp. 79-87.

Ferrandini, M., Ginsburg, L., Ferrandini, J., Rossi, P., 2000. Présence de Pomelomeryx boulangeri (Artiodactyla, Mammalia) dans l'Oligocène supérieur de la région d'Ajaccio (Corse) : étude paléontologique et conséquences. Comptes Rendus de l'Académie des Sciences 331, 675-681.

Funedda, A., Pertusati, P.C., Carmignani, L., Uras, V., Pisanu, G., Murtas, M., 2011. Note Illustrative della Carta Geologica d'Italia alla scala 1:50.000. In: Foglio 540 Cagliari. Servizio Geologico d'Italia, Regione Autonoma della Sardegna, S.EL.CA, Firenze.
Gandolfi, R., Porcu, A., 1967. Contributo alla conoscenza delle microfacies mioceniche delle colline di Cagliari (Sardegna). Rivista Italiana di Paleontologia e Stratigrafia 73, 313-348.

Gennari, P., 1868. Di un coccodrillo fossile nel terreno pliocenico di Cagliari. Atti dell'Accademia dei Fisiocritici di Siena 2, 127-129.

Georgalis, G.L., Villa, A., Vlachos, E., Delfino, M., 2016. Fossil amphibians and reptilesfrom Plakias. Crete: a glimpse into the earliest late Miocene herpetofaunas ofsoutheastern Europe. Geobios 49, 433-444.

Georgalis, G.L., Zoboli, D., Pillola, G.L., Delfino, M., 2017. A revision of the trionychid turtle Procyclanorbis sardus Portis, 1901 from the late Miocene of Sardinia (Italy). Annales de Paléontologie 103, 127-134.

Gerali, F., 2012. L'opera e l'archivio spezzino di Giovanni Capellini, un geologo dell'ottocento. In: Museo Geologico Giovanni Capellini. Editrice Himolah, Alma Mater Studiorum - Università di Bologna [106 pp.].

Gerali, F., 2014. Science and life of a geologist through his papers. The personal archive of Giovanni Capellini in La Spezia. Earth Sciences History 33, 122-149.

Jouve, F., Bouya, B., Amaghzaz, M., Meslouh, S., 2014. Maroccosuchus zennaroi (Crocodylia: Tomistominae) from the Eocene of Morocco: phylogenetic and palaeobiogeographical implications of the basalmost tomistomine. Journal of Systematic Palaeontology 13, 421-445, http://dx.doi.org/10.1080/14772019.2014.913078.

Klembara, J., Rummel, M., 2018. New material of Ophisaurus, Anguis and Pseudopus (Squamata, Anguidae, Anguinae) from the Miocene of the Czech Republic and Germany and systematic revision and palaeobiogeography of the Cenozoic Anguinae. Geological Magazine 155, 20-44.

Kotsakis, T., 1985. Les Trionychidae (Testudinata, Reptilia) fossiles de l'Italie. Bollettino della Società Paleontologica Italiana 24, 161-168.

Kotsakis, T., Delfino, M., Piras, P., 2004. Italian Cenozoic crocodilians: taxa, timing and biogeographic implications. Palaeogeography, Palaeoclimatology, Palaeoecology 210, 67-87.

Kotsakis, T., Palombo, M.R., 1979. Vertebrati continentali e paleogeografia della Sardegna durante il Neogene. Annales Géologiques des Pays Helléniques 2, 621-630 [Tome Hors Série].

Lovisato, D., 1892. Nuovi resti di coccodrilliano fossile nel Miocene di Nurri. Att della Regia Accademia dei Lincei 1, 436-439.

Marras, G.F., Ventura, G., 1985. Denti di coccodrilliano rinvenuti nel Miocene di Florinas. Bollettino della Società Sarda di Scienze Naturali 24, 13-25.

Mas, G., Antunes, M.T., 2008. Presència de Tomistomacf.lusitanica (Vianna i Moraes, 1945) (Reptilia: Crocodylia) al Burdigalià inferior de Mallorca (Illes Balears, Mediterrània occidental). Implicacions paleoambientals. Bolletí de la Societat d'Història Natural de les Balears 51, 131-146.

Mennecart, B., Zoboli, D., Costeur, L., Pillola, G.L., 2017. Reassessment of the ruminant from Sardara, the last non-insular mammal from Sardinia (Italy). Neues Jahrbuch für Geologie und Paläontologie 286, 97-104.

Mennecart, B., Zoboli, D., Costeur, L., Pillola, G.L., 2019. On the systematic position of the oldest insular ruminant Sardomeryx oschiriensis (Mammalia, Ruminantia) and the early evolution of the Giraffomorpha. Journal of Systematic Palaeontology 17, 691-704.

Nojima, K., Itoigawa, J., 2017. Tomistominae gen. et sp. indet. (Crocodylia: Crocodylidae) from the Lower Yage Formation (Middle Pleistocene) in Hamamatsu City Shizuoka Prefecture, Japan. Bulletin of the Mizunami Fossil Museum 43, 35-46.

Oudet, J., Münch, P.H., Verati, C., Ferrandini, M., Melinte-Dobrinescu, M., Gattacecca, J., Cornée, J.J., Oggiano, G., Quillévéré, F., Borgomano, J., Ferrandini, J. 2010. Integrated chronostratigraphy of an intra-arc basin: $40 \mathrm{Ar} / 39 \mathrm{Ar}$ datings, micropalaeontology and magnetostratigraphy of the early Miocene Castelsardo basin (northern Sardinia, Italy). Palaeogeography, Palaeoclimatology, Palaeoecology 295, 293-306.

Palombo, M.R., 1985. I grandi mammiferi pleistocenici delle isole del Mediterraneo: tempi e vie di migrazione. Bollettino della Società Paleontologica Italiana 24 201-224.

Palombo, M.R., 2009. Biochronology, paleobiogeography and faunal turnover in western Mediterranean Cenozoic mammals. Integrative Zoology 4, 367-386.

Pillola, G.L., Zoboli, D., 2017. Dwarf mammoth footprints from the Pleistocene of Gonnesa (southwestern Sardinia, Italy). Bollettino della Società Paleontologica Italiana 56, 57-64.

Piras, P., Delfino, M., Del Favero, L., Kotsakis, T., 2007. Phylogenetic position of thecrocodylian Megadontosuchus arduini (de Zigno, 1880) and tomistomine palaeo-biogeography. Acta Palaeontologica Polonica 52, 315-328.

Portis, A., 1901a. Il Palaeopython sardus Port. Nuovo pitonide del Miocene medio della Sardegna. Bollettino della Società Geologica Italiana 20, 247-253.

Portis, A., 1901b. Il Procyclanorbis sardus Port., nuovo trionychide fossile dellaSardegna. Bollettino della Società Geologica Italiana 20, 51-79.

Rossmann, T., Berg, D.E., Salisbury, S., 1996. Studies on Cenozoic crocodiles: 3 Gavialosuchus cf. gaudensis (Eusuchia: Tomistomidae) from the lower Miocene of south Germany. Neues Jahrbuch für Geologie und Paläontologie Monatschefte 1996 (6), 321-330.

Shan, H.-Y., Wu, X.-C, Cheng, Y.-N., Sato, T., 2017. Maomingosuchus petrolica, a restudy of "Tomistoma" petrolica Yeh, 1958. Palaeoworld 26, 672-690.

Sindaco, R., Doria, G., Razzetti, E., Bernini, F., 2006. Atlante degli Anfibi e dei Rettili d'Italia/Atlas of Italian Amphibians and Reptiles. Societas Herpetologica Italica Edizioni Polistampa, Firenze, pp. 791.

Sowerbutts, A., 2000. Sedimentation and volcanism linked to multiphase rifting in an Oligo-Miocene intra-arc basin, Anglona Sardinia. Geological Magazine 137, 395-418. 
Spano, S., 1985. Nuova segnalazione di resti di coccodrillo nel Miocene della Sardegna. Bollettino della Società Sarda di Scienze Naturali 24, 1-12.

Taplin, L.E., Grigg, G.C., 1989. Historical zoogeography of the eusuchian crocodilians: a physiological perspective. American Zoologist 29, 885-901.

Tschopp, E., Villa, A., Camaiti, M., Ferro, L., Tuveri, C., Rook, L., Arca, M., Delfino, M. 2018. The first fossils of Timon (Squamata: Lacertinae) from Sardinia (Italy) and possible causes for its local extinction in the Pleistocene. Zoological Journal of the Linnean Society 20,1-32 [Online first].

Van der Made, J., 1999. Biogeography and stratigraphy of the Mio-Pleistocene mammals of Sardinia and the description of some fossils. In: Reumer, J.W.F., de Vos, J. (Eds.), Elephants have a snorkel! Papers in honour of P. Y, 7. Deinsea, Sondaar, pp. 337-360.

Van der Made, J., 2008. New endemic large mammals from the Lower Miocene of Oschiri (Sardinia): observations on evolution in insular environment. Quaternary International 182, 116-134.

Vardabasso, S., 1962. Questioni paleogeografiche relative al Terziario antico della Sardegna. Memorie della Società Geologica Italiana 3, 655-673.

Venczel, M., Sanchiz, B., 2006. Lower Miocene Amphibians and reptiles from Oschiri (Sardinia, Italy). Hantkeniana 5, 72-75.

Vianna, A., Moraes, A., 1945. Sur un crane de crocodile fossile découvert dans le miocène de Lisbonne. Boletim da Sociedade Geologica del Portugal 4, 161-170.

Weems, R.E., 2006. Crocodilians from the Miocene of Maryland and Virginia. The geology and paleontology of Calvert Cliffs, 1. The Ecphora Miscellaneous Publications, pp. 30-35 [37 pp.]

Wilkens, B., 2003. Archeozoologia. Manuale per lo studio dei resti faunistici dell'area mediterranea [CD rom. Schio].
Zoboli, D., 2017. I vertebrati quaternari sardi conservati nel Naturhistorisches Museum di Basilea (Svizzera). Museologia Scientifica - Nuova Serie 11, 70-76.

Zoboli, D., Caddeo, G.A., 2016. Articulated skeletons of Prolagus sardus (Mammalia, Lagomorpha) from the Quaternary of Grotta del Campanaccio (Santadi, southwestern Sardinia). Bollettino della Società Paleontologica Italiana 55, 81-83.

Zoboli, D., Pillola, G.L., 2016a. Quaternary mammal fauna from “Surconis", Bolotana (Sardinia, Italy). Bollettino della Società Paleontologica Italiana 55, 193-203.

Zoboli, D., Pillola, G.L., 2016b. I rettili miocenici conservati nel Museo Sardo di Geologia e Paleontologia Domenico Lovisato (Cagliari, Italia). Museologia Scientifica - Nuova Serie 10, 81-87.

Zoboli, D., Pillola, G.L., 2017a. Upper Pleistocene mammal assemblage from Su Concali Quarry (Samatzai, southern Sardinia, Italy). Rivista Italiana di Paleontologia e Stratigrafia 123, 243-254.

Zoboli, D., Pillola, G.L, 2017b. Early Miocene insular vertebrates from Laerru (Sardinia, Italy): preliminary note. Rivista Italiana di Paleontologia e Stratigrafia 123 $149-158$.

Zoboli, D., Pillola, G.L., Palombo, M.R., 2018. The remains of Mammuthus lamarmorai (Major, 1883) housed in the Naturhistorisches Museum of Basel (Switzerland) and the complete "Skeleton-Puzzle". Bollettino della Società Paleontologica Italiana 57, 45-57.

Zoboli, D., Pillola, G.L., Rook, L., 2016. New remains of Macaca majori Azzaroli, 1946 (Primates, Cercopithecidae) from Is Oreris (Fluminimaggiore, southwestern Sardinia). Bollettino della Società Paleontologica Italiana 55, 227-230. 